\title{
Anything You Can Do, I Can Do Better-Except in Big Tech?: Antitrust's New Inhospitality Tradition
}

Elyse Dorsey ${ }^{*}$

\author{
Anything you can do, I can do better \\ I can do anything better than you \\ No, you can't \\ Yes, I can \\ No, you can't. . \\ Yes, I can! Yes, I can! ${ }^{1}$
}

INTRODUCTION

Competition is deeply woven into the fabric of our American heritage. No small amount of competitive spirit helped drive the Founders' efforts to design and to establish "a more perfect Union" - a unique political structure intended to improve upon what the world had observed to date. That competitive spirit drove us to push and to expand boundaries of all sorts over the last (nearly) 250 years. It manifests in scientific, mathematic, medical, and technological developments and other academic endeavors; in ubiquitous athletic programs; and even in our art and entertainment, including in the lyrics to Broadway musicals.

It is perhaps unsurprising, then, that competition has also been a foundational principle guiding the American economy since its inception. ${ }^{3}$ Competition has been the primary code by which firms live and die, succeed and fail, win and lose. This code has led directly to tremendous achievements that revolutionized not only our country, but the worldsuch as the Ford assembly line, which transformed an industry; the advent

\footnotetext{
* Adjunct Professor, Antonin Scalia Law School at George Mason University. I would like to thank John Yun, Roger Alford, Thom Lambert, Jessica Dutra, Kristian Stout and Josh Wright for valuable discussion on these (and many other) issues. I would also like to thank the Kansas Law Review Board for hosting this symposium and for providing an invaluable opportunity to discuss these important issues. The views expressed in this Article are my own.

1. Irving Berlin, Anything You Can Do (I Can Do Better), in ANnIE Get Your Gun (Richard Rodgers \& Oscar Hammerstein II, 1946).

2. U.S. CONST. pmbl.

3. See Standard Oil Co. v. FTC, 340 U.S. 231, 248 (1951) ("The heart of our national economic policy long has been faith in the value of competition.").
} 
of the personal computer which transformed much more than just an industry; and the introduction of cell phones and smart phones, which have dramatically expanded our access to information and our ability to interact with the world around us.

Keeping our markets competitive has, accordingly, also been a longstanding high priority. ${ }^{4}$ The focus of concern has shifted and adapted over the years as the economy itself has developed and expanded. Today, the question of how competition is - or is not-functioning in the big tech space has become a particularly compelling topic. The last several years have seen an increasing popular interest in antitrust, and it appears that wave of interest may soon be cresting. As the next presidential election nears, the candidates' focus upon antitrust and big tech issues seems unlikely to dissipate. Indeed, the seemingly unprecedented prominence of antitrust among presidential candidates has led commentators to speculate that, "Antitrust has become such a big deal that it seems certain to be a dominant theme in the presidential election - the last time that happened was 1912 - making 2020 the year of the great antitrust reawakening., 5

Rhetoric has grown increasingly aggressive, and the list of alleged ills is long. Companies are simply too big, too influential, too powerful; they are destroying our democracy and undermining our social values. ${ }^{6}$ While allegations run the gambit, under particular attack are tech firms that operate in multiple, complementary markets. Amazon is allegedly abusing its market position by selling its own products on its platform in competition with other retailers. ${ }^{7}$ Google is allegedly unlawfully

4. See Nat'l Soc'y of Prof'l Eng'rs v. United States, 435 U.S. 679, 695 (1978) (quoting Standard Oil, 340 U.S. at 248).

5. Joe Nocera, The Great Antitrust Awakening Can't Be Stopped, BloOMBERG BUSINESSWEeK (Oct. 24, 2019, 3:00 AM), https://www.bloomberg.com/news/features/2019-10-24/2020-will-be-anti trust-s-great-awakening [https://perma.cc/C3GL-P748].

6. See, e.g., Elizabeth Warren, Here's How We Can Break Up Big Tech, MEDIUm (Mar. 8, 2019), https://medium.com/@teamwarren/heres-how-we-can-break-up-big-tech-9ad9e0da324c [https://perma.cc/Q4KC-V9S7] ("Today's big tech companies have too much power- too much power over our economy, our society, and our democracy."); Russell Brandom, The MonopolyBusting Case Against Google, Amazon, Uber, and Facebook, THE Verge (Sept. 5, 2018, 8:14 AM), https://www.theverge.com/2018/9/5/17805162/monopoly-antitrust-regulation-google-amazon-uber -facebook [https://perma.cc/T935-8SQY] (describing several antitrust theories and complaints against big tech companies); Lina Khan \& Sandeep Vaheesan, Market Power and Inequality: The Antitrust Counterrevolution and Its Discontents, 11 HARV. L. \& POL'Y REV. 235, 235-36 (2017) (arguing that modern antitrust enforcement has allowed too much consolidation, which in turn contributes to market power which exacerbates economic inequality); Matt Stoller, The Return of Monopoly, NEW REPUBLIC (July 13, 2017), https://newrepublic.com/article/143595/return-monopoly-amazon-rise-business -tycoon-white-house-democrats-return-party-trust-busting-roots [https://perma.cc/U284-NG6M] (arguing firms today often have too much economic power, and that "[i]ncreasing concentration of ownership has [] led to unprecedented levels of corporate crime").

7. See, e.g., Lina M. Khan, Note, Amazon's Antitrust Paradox, 126 YALE L.J. 710 (2017); Alex 
monopolizing its position in the search engine market by preferencing its own products and content associated with its platform. ${ }^{8}$ Facebook is wielding its substantial market position to increasingly keep users on its platforms (and away from competitors' platforms). ${ }^{9}$ Apple is allegedly abusing its market position by establishing coercive terms of service on its App Store. ${ }^{10}$ The theme common to each of these allegations (and more) is that antitrust scrutiny is increasingly targeting tech firms' entry into, conduct within, and business decisions regarding markets complementary to those in which the relevant firm found its original success.

To combat these purportedly pervasive monopolies, a slew of increasingly radical proposals have been made. These companies need to be broken up; they should be regulated like utilities; vertical integration must be banned. ${ }^{11}$ Senator and Democratic presidential primary candidate Elizabeth Warren, for instance, has heavily criticized tech companies for entering into complementary and adjacent spaces, arguing: "You can run the platform - that is, you can be the umpire - or you can have a team in the game .... But you don't get to do both at the same time because that's not a level playing field for anyone else."12 In response, she calls for regulating platforms like utilities and breaking them apart from

Shephard, How Amazon Is Changing the Whole Concept of Monopoly, New RePUBLIC (June 19, 2017), https://newrepublic.com/article/143376/amazon-changing-whole-concept-monopoly [https://perma.cc/V544-J78W].

8. See, e.g., James Titcomb, Google Still Abusing Search Engine Monopoly, Rivals Tell EU, THE TELEgRAPH (Feb. 28, 2018, 2:06 PM), https://www.telegraph.co.uk/technology/2018 /02/28/google-still-abusing-search-engine-monopoly-rivals-tell-eu/ [https://perma.cc/G8YY-6F5W]; Google's Anticompetitive Practices Hurt Consumers, FAIRSEARCH (July 12, 2011), http://fairsearch .org/googles-anticompetitive-practices-hurt-consumers/ [https://perma.cc/8MJZ-R7Z6]; Benjamin Edelman \& Benjamin Lockwood, Measuring Bias in "Organic" Web Search, BENEDELMAN.ORG (Jan. 19, 2011), http://www.benedelman.org/searchbias/ [https://perma.cc/N2SY-7AZZ].

9. See, e.g., Laleh Ispahani, Facebook's Monopoly Power Threatens Democracy Itself, OPEN SOC'Y FOUNDS. (Nov. 5, 2019), https://www.opensocietyfoundations.org/voices/facebooks -monopoly-power-threatens-democracy-itself [https://perma.cc/9LC3-2JV8]; Josh Hawley, Opinion, We Might Be Better Off if Facebook, Instagram and Twitter Vanished: Sen. Josh Hawley, USA TODAY (May 22, 2019, 3:30 AM), https://www.usatoday.com/story/opinion/2019/05/22/facebook-instagramtwitter-do-more-harm-than-good-column/3751735002/ [https://perma.cc/5ZZB-VJXL]; Antonio Garcia Martinez, Facebook Is Not a Monopoly, But It Should Be Broken Up, WIRED (Mar. 14, 2019, 7:00 AM), https://www.wired.com/story/facebook-not-monopoly-but-should-broken-up/ [https:// perma.cc/7RGX-ZH84].

10. See, e.g., Charlie Wood, Apple CEO Tim Cook Says Monopolies Aren't Bad If They Aren't Abused, BUS. INSIDER (Dec. 11, 2019, 5:37 AM), https://www.businessinsider.com/tim-cook-apple -monopolies-not-bad-if-not-abused-2019-12 [https://perma.cc/EHP7-CU6S]; Lauren Feiner, App Makers Sue Apple and Claim It Uses 'Monopoly Power' to Charge Fees, CNBC (June 5, 2019, 11:17 AM), https://www.cnbc.com/2019/06/05/app-makers-sue-apple-and-claim-it-uses-monopoly-power -to-charge-fees.html [https://perma.cc/35NV-MFBE].

11. See, e.g., Warren, supra note 6; Stoller, supra note 6. See generally Khan, supra note 7.

12. Jessica Taylor, Sen. Elizabeth Warren Blasts Big Tech, Advocates Taxing Rich in 2020 Race, NPR (Mar. 15, 2019, 5:00 AM), https://www.npr.org/2019/03/15/702707734/sen-elizabeth-warren -takes-longtime-fight-for-a-level-playing-field-to-2020-race [https://perma.cc/AK2F-47RK]. 
participants on the platform. ${ }^{13}$ These arguments echo the sentiment that competing in multiple spaces is, somehow, inherently harmful to competition.

This rhetoric is eerily similar to that of a bygone era of antitrust enforcement - namely, the time when the inhospitality tradition prevailed. By the middle of the 20th century, antitrust courts routinely-often summarily-condemned any contract or behavior they deemed to be nonstandard or unusual. This approach reflected an extreme hostility to firm behavior - a hostility that seems to be making a resurgence todayand led to the coining of the phrase "inhospitality tradition" to describe the prevailing antitrust regime.

The inhospitality tradition often led to incoherent, nonsensical outcomes. Courts condemned conduct that made firms better competitors in the name of preserving competition. ${ }^{14}$ And they ignored the actual or likely competitive effects of conduct before them because they found the form of that conduct offensive. ${ }^{15}$ The courts eventually abandoned this approach. As economic learning advanced and court experience grew, the negatives of condemning as per se unlawful large swaths of firm conduct on the basis of its form - rather than its effects - crystalized and could no longer be ignored. From this new economic learning, economists and scholars came to realize that many procompetitive reasons can, and often do, underlie much of the conduct that had been summarily condemned. And they learned that judging the conduct on its face, much like judging a book by its cover, tended to yield inferior outcomes. Not only in the immediate sense, wherein consumers suffered in the cases before themsometimes in the form of admittedly higher prices on items like shoes and groceries $^{16}$ - but also longer term. If firms were routinely condemned for pioneering new ways to satisfy consumer demands, they would become more reluctant to even try, and competition within and across industries would be dampened. Accordingly, the courts since this time have

13. Warren, supra note 6 .

14. See, e.g., United States v. Von's Grocery Co., 384 U.S. 270, $296-97$ (1966) (Stewart, J., dissenting) ("In a sense, the defendants are being punished for the sin of aggressive competition."); United States v. Topco Assocs., Inc., 405 U.S. 596, 600 (1972) (condemning conduct while acknowledging it "improved the competitive potential of" the defendants); Aaron Director \& Edward H. Levi, Law and the Future: Trade Regulation, 17 Miss. C.L. REV. 7, 11 ("Perhaps, then the successful competitor can be turned upon when he wins, because he has been told not to compete.").

15. See infra Section I.A.

16. See Brown Shoe v. United States, 370 U.S. 294, 344 (1962) (accepting that "occasional higher costs and prices might result from" its interpretation and holding); Utah Pie Co. v. Cont'l Baking Co., 386 U.S. 685, 699-700 (1967) (condemning conduct that resulted in lower prices because it impaired a competitor's ability to compete); United States v. Trans-Missouri Freight Ass'n, 166 U.S. 290, 32324 (1897) ("[m]ere reduction in the price of the commodity dealt in" was not a compelling reason to permit conduct). 
repeatedly and consistently emphasized the importance of relying upon new economic learning and upon the evidence of likely effects in crafting antitrust policy and decisions.

Yet today, big tech critics frequently call for a policy of condemnation detached from effects, and for a regression back to the pre-new economic learning era. The potential harms from adopting such an approach likely cannot be overstated. The prospect of unfettered growth drives firms to compete harder - to find innovative ways to lower prices, to create new products, or to offer new services. ${ }^{17}$ As history has illustrated, impairing that prospect can have commensurate negative impacts upon how aggressively firms compete. Limiting growth and expansion explicitly would have a particular propensity to destroy incentives to compete. In a space like big tech-where innovation and competition has been so critical to driving tremendous consumer benefits, and which has become such an integral component of the modern economy-destroying any competitive impulse risks eliminating immense value.

Part I of this Article delves into the history of the inhospitality tradition within antitrust law, tracing its rise and demise. Part II explicates the apparent resurgence of hostile sentiment, particularly as applied to the tech context. Part III then investigates whether there is evidence of a market failure in big tech. Part IV analyzes what may — or may not—be warranted given the current state of the empirical literature.

\section{THE RISE AND FALL OF ANTITRUST’S INHOSPITALITY TRADITION}

Early antitrust law was characterized by numerous shortcomings - it was criticized as being internally inconsistent, incoherent, and largely unpredictable $^{18}$ (with the caveat that government plaintiffs would always

17. See Verizon Commc'ns Inc. v. Law Offices of Curtis V. Trinko, LLP, 540 U.S. 398, 407 (2004) ("The mere possession of monopoly power, and the concomitant charging of monopoly prices, is not only not unlawful; it is an important element of the free-market system. The opportunity to charge monopoly prices - at least for a short period - is what attracts 'business acumen' in the first place; it induces risk taking that produces innovation and economic growth.").

18. See William E. Kovacic \& Carl Shapiro, Antitrust Policy: A Century of Economic and Legal Thinking, 14 J. ECON. PERSPS. 43, 44 (2000) ("Most economists in the late 19th century scorned the Sherman Act. At best, the statute seemed a harmless measure incapable of halting an irresistible trend toward firms of larger scale and scope. At worst, the law would impede attainment of superior efficiency promised by new forms of industrial organization." (internal citations omitted)); Herbert Hovenkamp, Progressive Antitrust, 2018 U. ILL. L. REV. 71, 85 (2018) (noting court decisions during this time "completely destroyed the very small, locally owned businesses that the decisions were intended to protect"); Joshua D. Wright et al., Requiem for a Paradox: The Dubious Rise and Inevitable Fall of Hipster Antitrust, 51 ARIZ. ST. L.J. 293, 352 (2019) (examining the history and explaining that "it is widely acknowledged by commentators across the political spectrum that prior to the antitrust revolution, antitrust jurisprudence was an incoherent and unpredictable body of law 
prevail $\left.{ }^{19}\right)$. Many of these shortcomings derived from the attempt to maximize numerous, often conflicting, values via the antitrust laws. ${ }^{20}$ Embedded within this conflicting value system was an instinctive skepticism of firms that were considered too big or conduct that was considered too new. ${ }^{21}$ This skepticism manifested in an hostility that would come to define an era of antitrust enforcement.

But this era would come and pass - and for good reason. In response to intense criticism, both economists and jurists updated their priors. Economists devoted tremendous efforts to better understanding the reasons underlying various firm decisions, focusing more rigorously upon the effects of these decisions, and how best to craft antitrust policy in light of those effects. ${ }^{22}$ These efforts led to important insights, and ultimately

that frequently showed hostility to business"); Elyse Dorsey \& Jonathan M. Jacobson, Exclusionary Conduct in Antitrust, 89 ST. JOHN's L. REV. 101, 108 (2015) (noting that scholars analyzing antitrust jurisprudence up to the mid-twentieth century "in many cases[] found antitrust to be a meandering and incoherent jumble"); Douglas H. Ginsburg, Originalism and Economic Analysis: Two Case Studies of Consistency and Coherence in Supreme Court Decision Making, 33 HARV. J.L. \& PUB. POL'Y 217, 217 (2010) ("Forty years ago, the U.S. Supreme Court simply did not know what it was doing in antitrust cases."); Neil W. Averitt \& Robert H. Lande, Using the "Consumer Choice" Approach to Antitrust Law, 74 ANTITRUST L.J. 175, 177 (2007) (describing the "'social and political values" paradigm of the 1960s and 1970s, which proved standardless and unduly hostile to business"); ROBERT H. BORK, THE ANTITRUST PARADOX: A POLICY AT WAR WITH ITSELF 7 (1978) (arguing the numerous goals articulated in antitrust cases were "mutually incompatible"); Trouble Begins in the "New" Sherman Act: The Perplexing Story of the A\&P Case, 58 YALE L.J. 969, 971 (1949) ("[I]n United States v. N.Y. Great Atlantic \& Pacific Tea Co., the Court of Appeals for the Seventh Circuit has upheld a criminal conviction in a situation where the defendant corporation represented the forces of competition, efficiency and change. The potential contradiction in the New Sherman Act is sharply exposed.").

19. Von's Grocery Co., 384 U.S. at 301 (Stewart, J., dissenting) (“The sole consistency that I can find is that in litigation under $\S 7$ [of the Clayton Act], the Government always wins."); Kovacic \& Shapiro, supra note 18, at 51 ("Most commentators today share Stewart's gloomy assessment of merger jurisprudence in the 1960s and view the Supreme Court's antipathy toward mergers and doubts about market forces as indefensible.").

20. See Joshua D. Wright \& Douglas H. Ginsburg, The Goals of Antitrust: Welfare Trumps Choice, 81 FoRDHAM L. REV. 2405, 2405 (2013) ("The Court interpreted the Sherman and Clayton Acts to reflect a hodgepodge of social and political goals, many with an explicitly anticompetitive bent, such as protecting small traders from more efficient rivals. The failure of antitrust law to promote competition and further consumer welfare over this period is unsurprising and inevitable...."); Ginsburg, supra note 18, at 217-18 ("The Court had read into the Sherman Act an assortment of vague and, ironically, anti-competitive social and political goals ....").

21. See United States v. Trans-Missouri Freight Ass'n, 166 U.S. 290, 323-26 (1897) (noting that the goals of the antitrust laws include protecting "small dealers and worthy men"); United States v. Aluminum Co. of Am. (Alcoa), 148 F.2d 416, 428 (2d Cir. 1945) (explaining antitrust laws are "based upon the belief that great industrial consolidations are inherently undesirable" and were intended to "put an end to great aggregations of capital because of the helplessness of the individual before them"); Von's Grocery Co., 384 U.S. at 284 (Stewart, J., dissenting) (goals of the antitrust laws were, inter alia, "to protect small businessmen and to stem the rising tide of concentration in the economy").

22. See generally Director \& Levi, supra note 14; Harlan M. Blake \& William K. Jones, In Defense of Antitrust, 65 Colum. L. ReV. 377 (1965); Harlan M. Blake \& William K. Jones, Toward a Three-Dimensional Antitrust Policy, 65 CoLuM. L. REV. 422 (1965); Robert H. Bork \& Ward S. 
helped to inform the courts and to evolve antitrust law beyond a jurisprudential approach based more upon instinctive beliefs than upon real-world evidence.

\section{A. Early Inhospitality in Antitrust}

Assistant Attorney General (AAG) Donald Turner is largely credited with coining the term "inhospitality tradition," which is commonly used to refer to the antitrust regime that had developed by the middle of the last century. In remarks reflecting on the state of antitrust law in the mid1960s, AAG Turner noted that he would approach certain "restrictions not hospitably in the common law tradition, but inhospitably in the tradition of antitrust law." 23 And with that, a new phrase capturing an existing phenomenon entered the antitrust lexicon.

But what, precisely, was the inhospitality tradition to which AAG Turner referred? Many have offered descriptions of a system wherein courts routinely condemned behavior based upon either the size of the firm - if a large competitor did something, it was likely unlawful—or the court's unfamiliarity with the conduct - if the conduct was not, in the court's view, a traditional way of conducting business (if it was unusual or nonstandard) it was likely unlawful. Judge Easterbrook, for instance, explained " $[\mathrm{t}]$ he tradition is that judges view each business practice with suspicion, always wondering how firms are using it to harm consumers. If the defendant cannot convince the judge that its practices are an essential feature of competition, the judge forbids their use." ${ }^{24}$

This skepticism was reflected in the ready condemnation - often upon a finding of per se illegality - in many cases and to many categories of conduct. Mergers were routinely condemned. ${ }^{25}$ Nearly all vertical arrangements were treated as per se unlawful. ${ }^{26}$ The Supreme Court in Dr.

Bowman, Jr., The Crisis in Antitrust, 65 Colum. L. ReV. 363 (1965); Robert H. Bork, Contrasts in Antitrust Theory: I, 65 Colum. L. REV. 401 (1965); Ward S. Bowman, Contrasts in Antitrust Theory: II, 65 Colum. L. ReV. 417 (1965).

23. Mark J. Niefer, Donald Turner, Vertical Restraints, and the Inhospitality Tradition of Antitrust, 82 ANTITRUST L.J. 389, 389-390 (2019) (quoting AAG Turner in his 1966 speech before the New York State Bar Association). Though as Niefer has explained, this cute turn-of-phrase in fact fails to capture the nuance and thoughtfulness AAG Turner actually devoted to analyzing such restraints. See id. at 390.

24. Frank H. Easterbrook, The Limits of Antitrust, 63 TEX. L. REV. 1, 4 (1984).

25. See, e.g., Von's Grocery Co., 384 U.S. at 278-79 (1966); United States v. Phila. Nat'l Bank, 374 U.S. 321, 323-24 (1963); Brown Shoe Co. v. United States, 370 U.S. 294, 346 (1962).

26. Hovenkamp, Progressive Antitrust, supra note 18, at 84 ("Antitrust policy from the New Deal through the early 1970 s became an economically irrational war on vertical integration of all types."); Herbert Hovenkamp, The Law of Vertical Integration and the Business Firm: 1880-1960, 95 IowA L. REV. 863, 879 (2010) [hereinafter Hovenkamp, The Law of Vertical Integration] ("The history of legal policy toward vertical integration in the United States reflects an extraordinary amount of antipathy."). 
Miles Medical Co. v. John D. Park \& Sons Co. ${ }^{27}$ for example, considered the lawfulness under the antitrust laws of minimum resale price requirements. The Court quickly found that such restrictions have "for their sole purpose the destruction of competition and the fixing of prices," were "injurious to the public interest and void," and were "not saved by the advantages which the participants expect to derive from the enhanced price to the consumer." ${ }^{28}$ Later, when examining the legality of maximum resale price maintenance, the Court found that such agreements were likewise per se unlawful as they, "no less than those [agreements] to fix minimum prices, cripple the freedom of traders and thereby restrain their ability to sell in accordance with their own judgment." ${ }^{29}$ Similarly, in Standard Oil Co. of California v. United States, the Court found that "[t]ying agreements serve hardly any purpose beyond the suppression of competition." ${ }^{30}$ Attempts by a manufacturer to impose territorial restrictions upon its retailers were also unlawful per se, being considered "so obviously destructive of competition that their mere existence is enough." 31

As Alan Meese has recognized, the Supreme Court's 1972 decision in United States v. Topco Associates, Inc. ${ }^{32}$ is particularly striking example of the inhospitality tradition in action. ${ }^{33}$ It is striking both because of its whole-hearted adoption of the hostile language and treatment that had characterized the antitrust regime leading up to this decision, and because inklings that the Court would soon move away from the inhospitality tradition had already begun to percolate-indeed, the potential procompetitive concerns the Court so summarily rejected in Topco would soon be considered critical to a fulsome antitrust analysis. ${ }^{34}$

In Topco, several small and medium regional supermarket operators formed a cooperative buying organization to procure and distribute private label products in exclusive areas. ${ }^{35}$ The Government alleged this exclusive

27. 220 U.S. 373 (1911), overruled by Leegin Creative Leather Prods., Inc. v. PSKS, Inc., 551 U.S. 877 (2007).

28. Id. at 408; see also United States v. Parke, Davis \& Co., 362 U.S. 29 (1960).

29. Kiefer-Stewart Co. v. Joseph E. Seagram \& Sons, Inc., 340 U.S. 211, 213 (1951), overruled by Copperweld Corp. v. Indep. Tube Corp., 467 U.S. 752 (1984).

30. 337 U.S. 293, 305 (1949).

31. United States v. Arnold, Schwinn \& Co., 388 U.S. 365, 379 (1967).

32. 405 U.S. 596 (1972).

33. Alan J. Meese, Competition and Market Failure in the Antitrust Jurisprudence of Justice Stevens, 74 FORDHAM L. REV. 1775, 1780-82 (2006).

34. See, e.g., White Motor Co. v. United States, 372 U.S. 253, 261 (1963) (noting this case was the "first case involving a territorial restriction in a vertical arrangement," and finding the Court knew "too little of the actual impact of both that restriction and the one respecting customers to reach a conclusion on the bare bones of the documentary evidence before" it).

35. 405 U.S. at 598. 
division of territories constituted a per se violation of the Sherman Act. ${ }^{36}$ While the district court disagreed and found in favor of the defendant, the Supreme Court later reversed. ${ }^{37}$ The district court's analysis of the conduct at issue remarkably resembles modern-day court analyses. It found that the introduction of private labels was "[p]erhaps the most competitively significant innovation of the national mass merchandisers." ${ }^{\text {" }}$ These private labels provided numerous benefits to supermarkets, including that they offered "higher profits on products equivalent in quality to national brands which, in turn, permit lower consumer prices on products of high quality"; allowed the supermarkets to exercise exclusive control over important aspects of the production process, including supply sources, quality standards, packaging design and procurement, and pricing and promotion; permitted the chains to bargain more favorably with national brand manufacturers and to purchase products on more advantageous terms; and provided greater merchandising flexibility. ${ }^{39}$ The district court further identified benefits that flowed directly to consumers, including lower consumer prices - on average, private label products were about twenty percent lower than advertised brand prices - and the "stimulation of additional innovation, lower prices, better quality and service from the national brand manufacturers." 40

Furthermore, the district court explicitly found the "only way that chains the size of Topco members can obtain volumes necessary to achieve effective and economically feasible private label competition with the larger chains is to become affiliated with a buying organization." ${ }^{41}$ An independent private label "would require an annual sales volume of $\$ 250$ million or more and in order to achieve optimum efficiency, the volume required would probably have to be twice that amount." ${ }^{42}$ Yet Topco members' annual sales volumes ranged from just $\$ 1.6$ million to nearly $\$ 183$ million, with eighteen of the twenty-six members "well under $\$ 100$ million." 43 Indeed, the court found that generally "Topco members have been independently unable to develop efficient or effective private label programs." 44 Moreover, as Topco members obtained the scale necessary

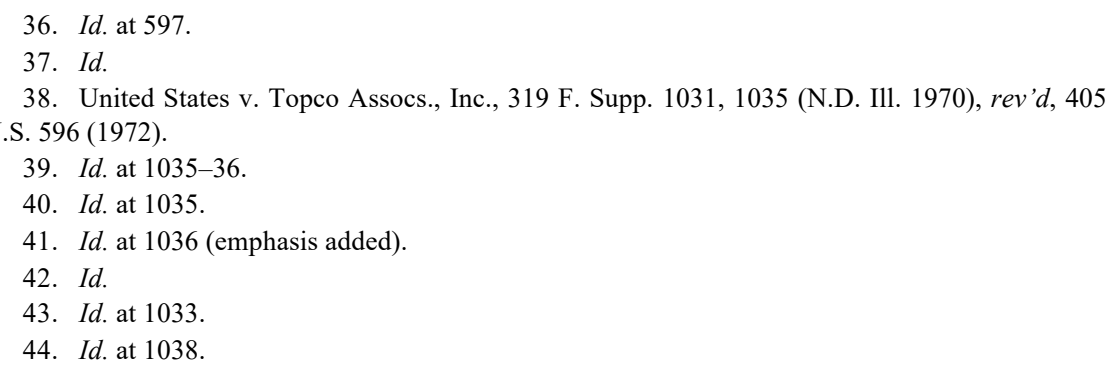


to "undertake a successful private label program on their own," many exited the buying cooperative. ${ }^{45}$ The court also found compelling evidence that the exclusive territorial restrictions were necessary for the Topco organization to exist at all. ${ }^{46}$ Ultimately, then, the lower court concluded that "[w]hatever anti-competitive effect these [exclusive] practices may have on competition in the sale of Topco private label brands is far outweighed by the increased ability of Topco members to compete both with national chains and other supermarkets operating in their respective territories." 47

Despite the thoughtful analysis the district court offered, the Supreme Court quickly found the conduct at issue constituted a violation of Section 1 of the Sherman Act - and a per se one, at that. ${ }^{48}$ The Supreme Court acknowledged the Topco members lacked any meaningful market power: Topco members' market shares ranged from one-and-a-half percent to sixteen percent, and averaged only about six percent. ${ }^{49}$ The Court further recognized that "only $10 \%$ of the total goods sold by Topco members $\mathrm{b}$ [ore] the association's brand names," and that the private label brands' "very existence [] improved the competitive potential of Topco members." 50

Nonetheless, the Court concluded the agreement was a horizontal territorial restraint and, accordingly, per se unlawful. ${ }^{51}$ It invalidated the efficiencies the lower court had so painstakingly scrutinized. ${ }^{52}$ And it explicitly rejected the idea that intrabrand restrictions could help facilitate interbrand competition. ${ }^{53}$ Thus, in the name of competition, the Court summarily condemned conduct that "improved the competitive potential" of the defendants before it. ${ }^{54}$

45. $I d$.

46. Id. at $1042-43$.

47. Id. at 1043 .

48. United States v. Topco Assocs., Inc., 405 U.S. 596, 608 (1972).

49. Id. at 600 .

50. Id.

51. Id. at 608 .

52. Id. at $610-11$.

53. Id. ("The District Court determined that by limiting the freedom of its individual members to compete with each other, Topco was doing a greater good by fostering competition between members and other large supermarket chains. But, the fallacy in this is that Topco has no authority under the Sherman Act to determine the respective values of competition in various sectors of the economy."); see also id. at 612 ("We also strike down Topco's other restrictions on the right of its members to wholesale goods .... Like territorial restrictions, limitations on customers are intended to limit intrabrand competition and to promote inter-brand competition. For the reasons previously discussed, the arena in which Topco members compete must be left to their unfettered choice absent a contrary congressional determination.").

54. Id. at 600 . 
While the lower court's analysis reads much like a modern-day antitrust decision-focusing upon the effects of the conduct before it - the Supreme Court's decision remained firmly rooted in the inhospitality tradition. But changes were already afoot, and the tide would soon shift. ${ }^{55}$ In that sense, Tорсо ends up representing the highwater mark of the inhospitality era.

\section{B. Establishing an Effects-Based Approach}

Beginning shortly before the Supreme Court's decision in Topco, and growing in force afterwards, was a movement away from the inhospitality tradition. Courts began to consider more rigorously the conduct before them. Whereas earlier courts often felt comfortable summarily condemning conduct, courts in the latter half of the twentieth century found a more critical review of the conduct - and of its effects - was in order.

This changing trend was the result of a combination of factors. As noted, antitrust jurisprudence leading up to this point was the subject of a tremendous amount of criticism for its numerous fundamental failures. ${ }^{56}$ At the same time, economic theory itself was developing in important ways that would ultimately affect the shape of the law. As scholars have noted, it was not merely populist notions underpinning the inhospitality tradition, but also prevailing economic theories, which likewise tended to reject any potential efficiency or procompetitive reasons for many restraints. ${ }^{57}$ This trend among economists led Nobel Laureate Ronald H. Coase to remark that "if an economist finds something ... that he does not understand, he looks for a monopoly explanation. And as in this field we are very ignorant, the number of ununderstandable practices tends to be rather large, and the reliance on a monopoly explanation, frequent."58

As economists responded to such criticisms, economic theory developed and gained a more comprehensive understanding of how and why firms might enter into differing arrangements, and the essentially

55. See, e.g., id. at 613 (Burger, J., dissenting) ("[W]e have here an agreement among several small grocery chains to join in a cooperative endeavor that, in my view, has an unquestionably lawful principal purpose; in pursuit of that purpose they have mutually agreed to certain minimal ancillary restraints that are fully reasonable in view of the principal purpose and that have never before today been held by this Court to be per se violations of the Sherman Act."); see also White Motor Co. v. United States, 372 U.S. 253, 261 (1963).

56. See supra notes 18-21 and accompanying text.

57. Alan J. Meese, In Praise of All or Nothing Dichotomous Categories: Why Antitrust Law Should Reject the Quick Look, 104 GEO L.J. 835, 851-52 (2016).

58. Ronald H. Coase, Industrial Organization: A Proposal for Research, in 3 POLICY ISSUES AND RESEARCH OPPORTUNITIES IN INDUSTRIAL ORGANIZATION 59, 67 (Victor R. Fuchs ed., 1972) [hereinafter Coase, Industrial Organization]. 
irrebuttable skepticism of many types of restraints began to dissipate. The notion that many of these restraints could yield real consumer benefitsand, accordingly, the notion that the likely effects of the restraints, rather than their form alone, should govern the analysis - began to take hold in the economic literature. ${ }^{59}$ The courts, in turn, followed suit. ${ }^{60}$

One of the earliest cases reflecting this more rigorous framework was Continental Television, Inc. v. GTE Sylvania, Inc., ${ }^{61}$ in which the Court reconsidered the per se treatment for vertical territorial restrictions a manufacturer imposed upon its retailers. Quite unlike in its Topco decision, the Court here recognized the "market impact of vertical restrictions is complex because of their potential for a simultaneous reduction of intrabrand competition and stimulation of interbrand competition." ${ }^{\prime 2}$ The Court explicitly recognized "a number of ways in which manufacturers can use such restrictions to compete more effectively against other manufacturers," 63 including by aligning incentives between themselves and their retailers, eliminating free-riding, and encouraging retailer investment of capital and labor. ${ }^{64}$ Whereas Topco rejected the notion that a reduction in intrabrand competition could be a cognizable benefit, the GTE Sylvania Court accepted that the modern economic understanding of competitive effects had developed to encompass a broader notion of how competition might operate in the real world-and updated its jurisprudence accordingly.

Another notable case arising just a couple years later was Broadcast Music, Inc. v. Columbia Broadcasting System, Inc. (BMI). ${ }^{65}$ This case, along with GTE Sylvania, is generally considered a turning point in antitrust law and the beginning of a real conception of efficiencies in antitrust precedent. ${ }^{66}$ In $B M I$ the Court was tasked with deciding whether

59. See, e.g., William E. Kovacic, The Influence of Economics on Antitrust Law, 30 ECON. INQUIRY 294, 301-03 (1992); see also Kovacic \& Shapiro, supra note 18, at 52-59; Wright et al., supra note 18, at 302-08; Dorsey \& Jacobson, supra note 18, at 108-14.

60. See, e.g., Kovacic \& Shapiro, supra note 18, at 52-59; Wright et al., supra note 18 , at 302 08; Dorsey \& Jacobson, supra note 18, at 114-17.

61. 433 U.S. 36 (1977).

62. Id. at 51 .

63. Id. at $54-55$.

64. Id. at 55 .

65. 441 U.S. 1 (1979).

66. See, e.g., Kovacic \& Shapiro, supra note 18, at 53 (describing GTE Sylvania as "[t] $]$ he pivotal event”); James C. Cooper et al., Vertical Antitrust Policy As a Problem of Inference, 23 INT'L J. INDUS. ORG. 639, 640 (2005) (describing GTE Sylvania as a "watershed" case in which "the Supreme Court eschewed its prior 'formalistic line drawing,' and instead based its decision on demonstrable economic effects"); William J. Kolasky \& Andrew R. Dick, The Merger Guidelines and the Integration of Efficiencies into Antitrust Review of Horizontal Mergers, 71 ANTITRUST L.J. 207, 214-15 (2003) (noting BMI and GTE Sylvania were two of the first cases in which the Supreme Court expanded its consideration of efficiencies in antitrust law generally). 
"blanket licenses to copyrighted musical compositions" at fees the American Society of Composers, Authors and Publishers (ASCAP) and BMI negotiated constituted per se unlawful price fixing. ${ }^{67}$ Examining the facts before it, the Court explained that "ASCAP and the blanket license developed together out of the practical situation in the marketplace: thousands of users, thousands of copyright owners, and millions of compositions." 68 The reality was that most users demanded "unplanned, rapid, and indemnified access to any and all of the repertory of compositions," while owners demanded a "reliable method of collecting for the use of their copyrights." ${ }^{\circ 9}$ The Court further found that the costs of negotiating individual licenses that could conceivably satisfy all these demands was prohibitive. ${ }^{70}$ To overcome this stalemate, the blanket license was born.

Given this backdrop, the Court held the per se rule was inappropriate. ${ }^{71}$ While offering the underlying product (the blanket licenses) literally required horizontal competitors to establish (or to fix) a price for that product, this literal view was, as it often is, "overly simplistic and [] overbroad." 72 The Court found that the blanket licenses created a whole that was "truly greater than the sum of its parts; it [wa]s, to some extent, a different product."73 Again, this analysis represents a distinct development and a willingness to consider the context and effects of the conduct under review that was missing from the Supreme Court's Topco decision. Topco members in fact created different products (the private label brand) that could not have existed otherwise, but the Court nonetheless summarily condemned their conduct.

Since then, the Court has continued its evolution beyond the inhospitality tradition, and modern antitrust law emphasizes heavily the importance of considering the likely effects of allegedly unlawful conduct. Indeed, the courts today embrace new economic learning and have repeatedly made clear that per se treatment is reserved for that conduct with which the court has sufficient, significant experience to say with confidence that it always or almost always will be harmful to

\footnotetext{
67. BMI, 441 U.S. at $4-7$.

68. Id. at 20

69. Id.

70. Id. (" $[\mathrm{A}] \mathrm{s}$ both the Court of Appeals and CBS recognize, the costs are prohibitive for licenses with individual radio stations, nightclubs, and restaurants, and it was in that milieu that the blanket license arose.").

71. Id. at 18

72. Id. at $8-9$.

73. Id. at $21-22$.
} 
competition. ${ }^{74}$ Likewise, the courts have consistently recognized that the "economics literature is replete with procompetitive justifications for" various vertical (and horizontal) arrangements. ${ }^{75}$

Despite this widespread agreement, commentators today are increasingly agitating for what would amount to a rejection of this new learning and a return to the inhospitality tradition. As developed below, these critics call for fundamental changes to the antitrust laws that would (among other things) prohibit, or presumptively prohibit, conduct that is evaluated under the rule of reason today because of its potential to yield significant procompetitive effects.

Before turning to those calls, it is worth noting one final case that seems squarely on point with regard to the current debate. In United States v. Microsoft, ${ }^{76}$ the D.C. Circuit was tasked with evaluating a situation very similar to what antitrust enforcers currently face-namely, new combinations of new products. In Microsoft, the court considered, among other issues, whether the contractual and technological bundling of Microsoft's Internet Explorer web browser (the tied product) with its Windows operating system (the tying product) constituted a per se unlawful tying arrangement. ${ }^{77}$ The court acknowledged—but did not pass judgment on-Microsoft's alleged efficiency arguments for the arrangement. ${ }^{78}$ It then remanded this claim to the district court, noting:

$[T]$ hese and other novel, purported efficiencies suggest that judicial 'experience' provides little basis for believing that, "because of their pernicious effect on competition and lack of any redeeming virtue," a software firm's decisions to sell multiple functionalities as a package should be "conclusively presumed to be unreasonable and therefore illegal without elaborate inquiry as to the precise harm they have caused or the business excuse for their use."

The Microsoft court, in other words, declined to return to the inhospitality

74. See, e.g., Cal. Dental Ass'n v. FTC, 526 U.S. 756, 781 (1999) (“The object is to see whether the experience of the market has been so clear, or necessarily will be, that a confident conclusion about the principal tendency of a restriction will follow from a quick (or at least quicker) look, in place of a more sedulous one. And of course what we see may vary over time, if rule-of-reason analyses in case after case reach identical conclusions."); BMI, 441 U.S. at 2, 9-10 (“" [I]t is only after considerable experience with certain business relationships that courts classify them as per se violations' .... We have never examined a practice like this one before." (quoting United States v. Topco Assocs., Inc., 405 U.S. 596, 607-08 (1972))); United States v. Microsoft, 253 F.3d 34, 84 (D.C. Cir. 2001) (same).

75. See Leegin Creative Leather Prods., Inc. v. PSKS, Inc., 551 U.S. 877, 889 (2007); see also Bus. Elecs. Corp. v. Sharp Elecs. Corp., 485 U.S. 717, 727-29 (1988); Cont'l Television, Inc., v. GTE Sylvania, Inc., 433 U.S. 36, 51, 55-56; BMI, 441 U.S. at 22.

76. 253 F.3d 34 (D.C. Cir. 2001).

77. Id. at 84 .

78. Id. at $89-90$.

79. Id. at 90-91 (quoting N. Pac. Ry. Co. v. United States, 356 U.S. 1, 5 (1958)). 
tradition in a case involving new and emerging technologies.

\section{INHOSPITALITY STRIKES BACK?}

Despite that courts and enforcers deliberately abandoned the inhospitality tradition - which had unduly condemned conduct that benefited consumers - this tradition currently seems to be experiencing renewed interest today. As tech firms continue to grow and to innovate new methods by which to permeate daily lives, skeptics express many of the same concerns as their counterparts did decades ago. Indeed, in response to an increase in the "number of ununderstandable practices," we seem to be seeing a commensurate rise in the "reliance on monopoly explanations." 80

These include arguments that tech companies are simply too "big," too "powerful," or too "influential" - or all of these things — and that enforcers should do more to constrain these forces. ${ }^{81}$ Such concerns have been expressed on numerous occasions and in various contexts. But one common thread appears to be a particular discomfort with vertical integration and related behaviors.

U.S. politicians, in particular, appear to embrace these lines of argument of late. There has been an uptick in political interest in antitrust generally - and, more recently, in how the antitrust laws apply in the tech space, specifically. The 2016 presidential election marked the first time in decades that antitrust was explicitly included in a major party platform. ${ }^{82}$ Since then, senators have introduced numerous pieces of legislation aimed at increasing antitrust enforcement. ${ }^{83}$ The Democratic Party's Better Deal, for instance, advocates for stronger structural presumptions that would fundamentally shift merger review, as well as for a "new consumer competition advocate" to advise the antitrust agencies,

80. Coase, Industrial Organization, supra note 58, at 67.

81. See infra Part III. This Part describes the proposals that have been made, before the article turns in Part III to analyzing the bases of these proposals.

82. See, e.g., Democratic Platform COMm., 2016 Democratic PARTy Platform 11 (2016), https://democrats.org/wp-content/uploads/2018/10/2016_DNC_Platform.pdf [https://perma.cc/6NET -RPBS]; Guy Rolnik, 140 Years of Antitrust: "Competition" in Democratic and Republican Platforms, PROMARKET (Oct. 11, 2016), https://promarket.org/140-years-antitrust-competition -democrat-republican-platforms/ [https://perma.cc/LF2F-BZ3G].

83. See, e.g., Monopolization Deterrence Act of 2019, S. 2237, 116th Cong. (2019) (as referred to the S. Comm. on the Judiciary, June 23, 2019); Merger Enforcement Improvement Act, S. 306, 116th Cong. (2019) (as referred to the S. Comm. on the Judiciary, Jan. 31, 2019); Consolidation Prevention and Competition Promotion Act of 2019, S. 307, 116th Cong. (2019) (as referred to the S. Comm. on the Judiciary, Jan. 31, 2019); Food and Agribusiness Merger Moratorium and Antitrust Review Act of 2018, S. 3404, 115th Cong. (2018) (as referred to the S. Comm. on the Judiciary, Aug. $28,2018)$ 
the U.S. Department of Justice's Antitrust Division and the Federal Trade Commission, in their enforcement efforts. ${ }^{84}$ In June 2019, the House Judiciary Committee announced it had launched a "bipartisan investigation into competition in digital markets," asserting a "small number of dominant, unregulated platforms have extraordinary power over commerce, communication, and information online." 85 And in July, the Department of Justice announced it was "reviewing whether and how market-leading online platforms have achieved market power and are engaging in practices that have reduced competition, stifled innovation, or otherwise harmed consumers." 86

Much of this interest harkens to the inhospitality tradition, in that its supporters often express wide-ranging skepticism of tech companies and their behavior. For instance, several presidential candidates have reiterated their support for breaking up - or for seriously considering breaking up-large tech firms on antitrust grounds. ${ }^{87}$ Senator Elizabeth Warren released an essay entitled Here's How We Can Break Up Big $T e c h^{88}$ and commissioned a billboard campaign in San Francisco with the slogan Break Up Big Tech. ${ }^{89}$ Her essay argues "big tech companies have too much power" and "have hurt small businesses and stifled innovation," and that "[w]eak antitrust enforcement has led to a dramatic reduction in competition and innovation in the tech sector." 90 In response, she argues an overhaul of our laws is required, proposing, among other things, that platforms be regulated as utilities. ${ }^{91}$ While Warren appears to be the most aggressively positioned, she is by no means the only one. For instance, former Vice President Joe Biden has said that breaking up big tech

84. Crack Down on Corporate Monopolies \& the Abuse of Economic and Political Power, A BETTER DEAL, https://abetterdeal.democraticleader.gov/the-proposals/crack-down-on-abuse-of -power/ [https://perma.cc/6ZPL-Q5VW] (last visited Apr. 8, 2020).

85. Press Release, House Comm. on the Judiciary, House Judiciary Committee Launches Bipartisan Investigation into Competition in Digital Markets (June 3, 2019), https://judiciary.house .gov/news/documentsingle.aspx?DocumentID=2051 [https://perma.cc/J9TF-74ET].

86. Press Release, U.S. Dep't of Justice, Office of Public Affairs, Justice Department Reviewing the Practices of Market-Leading Online Platforms (July 23, 2019), https://www.justice.gov/opa /pr/justice-department-reviewing-practices-market-leading-online-platforms [https://perma.cc/3J6A $-9 \mathrm{CZ} 3]$.

87. See, e.g., Warren, supra note 6 ("[W] need to stop this generation of big tech companies from throwing around their political power to shape the rules in their favor and throwing around their economic power to snuff out or buy up every potential competitor.").

88. See id.

89. Makena Kelly \& Nick Statt, Elizabeth Warren Puts a Giant Tech Breakup Billboard in San Francisco's Face, THE VERGE (May 29, 2019, 3:38 PM), https://www.theverge.com /2019/5/29/18644590/elizabeth-warren-break-up-big-tech-billboard-amazon-facebook-apple-google [https://perma.cc/B6AL-MU7Y].

90. Warren, supra note 6.

91. Id. 
companies is "something we should take a really hard look at"; Senator Bernie Sanders has advocated for breaking up such companies; Senator Amy Klobuchar has stated she would engage in an "aggressive retrospective review of mergers" and investigate big tech; Pete Buttigieg has said breakup "should be on the table." "92 Senator Josh Hawley has likewise decried Facebook's power in today's society and advocated for its demise. ${ }^{93}$

But this discussion and skepticism is not limited to political campaigns. Academics have made similar arguments. The level of inhospitality proposed varies - ranging from fully embracing such a regime to more modest suggestions that would change the margins, rather than the heart, of antitrust enforcement. On the more extreme end, some have advocated for banning vertical integration by dominant tech firms or platforms and for establishing presumptions of illegality for vertical restraints more generally. ${ }^{94}$ Lina Khan, in particular, argues that vertical integration in the tech space is particularly prone to creating "conflicts of interest," and contends that adopting a prophylactic ban on vertical growth or expansion "may prove more effective than policing these conflicts." 95 As developed further below, however, these alleged "conflicts of interest" are neither new nor unique to the tech or online platform spaces. ${ }^{96}$ And despite such conflicts, consumers often benefit from vertical growth and integration.

Similar, but slightly less dramatic, proposals call for limiting size or limiting vertical integration by acquisition, while preserving the ability of firms to expand vertically on their own. ${ }^{97}$ Harold Feld, for instance, expresses significant skepticism of vertical acquisition, but acknowledges

92. Elizabeth Culliford, Where U.S. Presidential Candidates Stand On Breaking Up Big Tech, REUTERS (Jan. 24, 2020, 5:20 AM), https://www.reuters.com/article/us-usa-election-tech-fact box/where-us-presidential-candidates-stand-on-breaking-up-big-tech-idUSKBN1ZN16C [https:// perma.cc/6UDW-T7PE].

93. Hawley, supra note 9.

94. See Khan, supra note 7, at 803 ("[R] estoring traditional antitrust principles to . . ban vertical integration by dominant platforms could help maintain competition in these markets."); Khan \& Vaheesan, supra note 6, at 280 ("Specifically, simple presumptions of illegality, subject to rebuttal through the introduction of credible business justifications, should govern, at a minimum, horizontal mergers in concentrated markets, monopolization, and vertical restraints."); see also TIM WU, THE CURSE Of Bigness: ANTITRUst IN THE NEW GiLdEd Age (2018) (calling for a return to the earlier, inhospitality regime era of enforcement).

95. Khan, supra note 7, at 793.

96. See infra Section III.B.

97. Harold Feld, Roosevelt Inst., The CASe for the Digital Platform Act: Market StRUCTURE AND REgulation OF Digital PlatForms 94-97 (2019), https://rooseveltinstitute.org /wp-content/uploads/2019/05/Case-for-the-Digital-Platform-Act-final.pdf [https:/perma.cc/LA9E $-\mathrm{RVZH}]$. 
the difficulties inherent to trying to stem organic vertical growth. ${ }^{98} \mathrm{He}$ argues that "digital platforms are unusual in that a combination of vertical features can enhance the overall complementary network effects they enjoy, thus increasing dominance by enhancing the cost of exclusion." 99 And he notes that Amazon's addition of Prime video does more than better position it to compete against YouTube: it also "enhances Amazon's overall value and the overall value of its Prime membership, enhancing its dominance in the online shopping market."100 This line of argumentmuch like the inhospitality tradition decisions of yore - acknowledges that a firm's behavior "enhances [its] overall value" the Topco Court's terms, "improved the competitive potential of" the firm ${ }^{102}$ - but nonetheless argues for condemning much of that very same conduct (just as the Topco Court did). In Feld's view, only a "handful of cases" demonstrating the necessity of allowing internal vertical growth save it from per se or presumptive condemnation. ${ }^{103}$

Other academics have proposed variants that focus upon nondiscrimination rather than upon outright bans on, or presumptions of illegality for, vertical integration. ${ }^{104}$ The Stigler Center, for example, released a report from a committee of academics on market structure and antitrust. ${ }^{105}$ The report argues that "antitrust law might be revised to relax the proof requirements imposed upon antitrust plaintiffs in appropriate cases or to reverse burdens of proof." 106 Among the recommendations, the report also argues that "[n]on-discrimination can be a helpful tool in creating a competitive environment in which entrants are protected and can thrive, while allowing a platform to vertically integrate to some degree." 107 The authors caution that "[n]on-discrimination requirements should be used only after careful study because they can also prevent

\footnotetext{
98. Id.

99. Id. at 93 .

100. Id.

101. Id.

102. United States v. Topco Assocs., Inc., 405 U.S 596, 600 (1972).

103. See Feld, supra note 97, at 94.

104. See Hal Singer, How To Tame Big Tech, Forbes (May 8, 2019, 7:01 AM), https:// www.forbes.com/sites/washingtonbytes/2019/05/08/how-to-tame-big-tech/\#589a9dba1fef [https:// perma.cc/GP8U-MRGJ]; Kevin Caves \& Hal Singer, When the Econometrician Shrugged: Identifying and Plugging Gaps in the Consumer Welfare Standard, 26 GEO. MASON L. REV. 395, 416-21 (2018) (explaining how a nondiscrimination standard could be employed for antitrust protections).

105. COMM. FOR THE StUdy OF Dig. Platforms, Stigler CTR. FOR THE STUdy OF THE ECON. \& THE STATE, MARKET STRUCTURE AND ANTITRUST SUBCOMMITTEE (2019), https://research.chicago booth.edu/-/media/research/stigler/pdfs/market-structure-report.pdf [https://perma.cc/24UY-65WB]. 106. Id. at 77 .

107. Id. at 93 .
} 
efficient forms of service that enhance competition." "108 Still other scholars advocate for generally increasing enforcement against vertical behavior. ${ }^{109}$

Nor is this increased skepticism limited to U.S. stakeholders. Hostility toward big tech behavior writ large has also burgeoned internationally. Several recently issued reports, authored or commissioned by foreign government agencies, appear to reflect an increasing hostility toward big tech growth and integration reminiscent of the inhospitality tradition. ${ }^{110}$ These reports seek to develop and articulate theories of potential harm arising in, broadly defined, the tech space or digital economy, and to provide solutions to purported harms. Proposals include new rules (like prohibiting integration or discrimination and flipping burdens), new powers for enforcers, and other policy prescriptions. Many of the recommendations explicitly embrace the notion that, when in doubt, courts and enforcers should presume vertical integration is harmful, and scrutinize closely proposed justifications.

EU Commissioner Margrethe Vestager, for example, commissioned a report "to explore how competition policy should evolve to continue to promote pro-consumer innovation in the digital age." 111 This report argues the error cost framework might need modifications in the digital or tech space, and identified specific ways in which such a realignment might be accomplished. ${ }^{112}$ It contends:

[In this space] one may want to err on the side of disallowing potentially anti-competitive conducts, and impose on the incumbent the burden of proof for showing the pro-competitiveness of its conduct. This may be true especially where dominant platforms try to expand to neighbouring

108. Id.

109. See, e.g., Carl Shapiro, Antitrust in a Time of Populism, 61 INT'L J. INDUS. ORG. 714, 73743 (2018) (arguing antitrust policy should, among other things, more tightly control mergers, and be tougher on "exclusionary conduct by dominant firms"); Steven C. Salop, Invigorating Vertical Merger Enforcement, 127 YALE L.J. 1962, 1982-84 (2018) (advocating for revised guidelines of vertical mergers and a more aggressive enforcement approach).

110. See Jacques Crémer, Yves-Alexandre de Montjoye \& Heike Schweitzer, Competition Policy for the Digital Era (2019), https://ec.europa.eu/competition/publications/reports/kd0419345enn.pdf [https://perma.cc/7XL3-4C43]; AUSTRALIAN COMPETITION \& CONSUMER COMM'N, DigITAL PLATFORMS INQUIRY: PRELIMINARY REPORT 1 (2018), https://www.accc.gov.au/system/files/ACCC \%20Digital\%20Platforms\%20Inquiry\%20-\%20Preliminary\%20Report.pdf [https://perma.cc/DFS36P9J]; COMM'N 'COMPETITION LAW 4.0', FeD. Ministry For ECON. AfFAirs \& ENERGy, A NeW COMPETITION FRAMEWORK FOR THE DigiTAL ECONOMY (2019), https://www.bmwi.de/Redaktion /EN/Downloads/a/a-new-competition-framework.pdf?blob=publicationFile \&v=2 [https://perma.cc /6ARK-S4SB]; Dig. COMPetition EXPert Panel, Unlocking Digital Competition (2019), https://assets.publishing.service.gov.uk/government/uploads/system/uploads/attachment_data/file/78 5547/unlocking_digital_competition_furman_review_web.pdf [https://perma.cc/6SLB-XDC4]; OFCOM, ONLINE MARKET FAILURES AND HARMS (2019), https://www.ofcom.org.uk/_data/assets /pdf_file/0025/174634/online-market-failures-and-harms.pdf [https://perma.cc/YJ7Y-AWRV].

111. Crémer, de Montjoye \& Schweitzer, supra note 110, at 2.

112. Id. at 4 . 
markets, thereby growing into digital ecosystems, which become ever more difficult for users to leave.

In other words, the report argues for an approach clearly hostile to actions - especially vertical actions - by tech firms.

This report makes additional, specific recommendations illustrating how this hostility might be accomplished in practice. For instance, it argues that in certain markets, the firm "should bear the burden of proving that self-preferencing has no long-run exclusionary effects on product markets." 114 Such recommendations disfavoring self-preferencing seem consistent with the approach the EU has taken in its recent cases, such as its 2017 decision against Google, which concluded that Google unlawfully preferenced its own shopping service on its search engine results pages. ${ }^{115}$

Similarly, the Australian Competition \& Consumer Commission (ACCC) issued its Digital Platforms Inquiry Preliminary Report in December 2018. ${ }^{116}$ The ACCC focused its report on analyzing specific platforms, particularly Google and Facebook. ${ }^{117}$ It found there "is a risk competition may be hindered due to the vertically integrated nature of Google and Facebook, and the fact that they have the ability and incentive to favour their own business interests," as well as a more general "risk that digital platforms may favour their own interests." "118 Indeed, the ACCC found " $[\mathrm{t}]$ he risk of competitive harm increases when the monopoly business is vertically integrated." "I19 In response, the ACCC noted it "is considering recommending a regulatory authority to monitor and report on these issues." 120

The German Federal Ministry for Economic Affairs and Energy

113. Id.

114. Id. at 7 .

115. See 2017 O.J. (Case AT.39740 - Google Search (Shopping)), https://eur-lex.europa.eu/legal -content/EN/TXT/?qid=1516198535804\&uri=CELEX:52018XC0112(01) [https://perma.cc/C8R4 -AA4M]; see also 2018 O.J. (Case AT.40099-Google Android), https://eur-lex.europa.eu/legal -content/EN/ALL/?uri=CELEX:52019XC1128(02) [https://perma.cc/DKK2-9N7R].

116. AuSTRALIAN COMPETITION \& CONSUMER COMM'N, supra note 110, at 1 ("On 4 December 2017, the then Treasurer, the Hon Scott Morrison MP, directed the Australian Competition and Consumer Commission (the ACCC) to hold an inquiry into the impact of online search engines, social media and digital content aggregators (digital platforms) on competition in the media and advertising services markets.").

117. Id. at $1-2$.

118. Id. at 80

119. Id. at 5 .

120. Id. at 66. The report explains further that a "regulatory authority should be tasked to monitor, investigate and report on whether digital platforms, which are vertically integrated and meet the relevant threshold, are engaging in discriminatory conduct (including, but not limited to, conduct which may be anti-competitive) by favouring their own business interests above those of advertisers or potentially competing businesses." Id. at 81 . 
likewise released a report from its Commission "Competition Law 4.0" in September 2019. ${ }^{121}$ This report "proposes that there should be an EU Platform Regulation establishing clear rules of conduct for dominant online platforms," which should "in particular include a ban on giving preferential treatment to the platform operator's own services over those of third parties." 122 Similarly, in a press release accompanying the report, one of the chairs of the Commission of Experts, Professor Achim Wambach, asserted that "[s]uch [dominant] platforms should be banned from giving themselves preferential treatment." 123

Agencies in the United Kingdom have also issued a couple recent reports. First, the Chancellor of the Exchequer and Secretary of State for Business, Energy and Industrial Strategy commissioned a report of outside academics assigned to a Digital Competition Expert Panel. ${ }^{124}$ This report focuses less on self-preferencing and vertical integration than some of the other reports. It does, however, recommend the government establish a "pro-competition digital markets unit, tasked with securing competition, innovation, and beneficial outcomes for consumers and businesses."

Most recently, the United Kingdom communications authority, Ofcom, released a report in October 2019, entitled Online Market Failures and Harms. ${ }^{126}$ This report attempts to systematically identify the kinds of harms that might arise in digital spaces. Like the other reports, it acknowledges that vertical integration might have some harmful effects. ${ }^{127}$ However, it also recognizes that such behaviors may offer very real consumers benefits, explaining that, "[i]n some instances, selfpreferencing by a large platform might enable it to enter in the provision of a new service in competition with a large incumbent platform. In such a scenario, a blanket ban on self-preferencing for large platforms might

121. See COMM'N 'COMPETITION LAW 4.0,' supra note 110.

122. Id. at 2; see also id. at 3 (Recommendation 10 says: "The Commission 'Competition Law 4.0 ' recommends that dominant online platforms that fall under the Platform Regulation be prohibited from favouring their own services in relation to third-party providers unless such preferencing is objectively justified.").

123. Press Release, Fed. Ministry for Econ. Affairs \& Energy, Commission of Experts on Competition Law 4.0 Presents Final Report to Minister Altmaier: A New Competition Framework for the Digital Economy (Sept. 9, 2019), https://www.bmwi.de/Redaktion/EN/Pressemitteilungen /2019/20190909-commission-of-experts-on-competition-law-40-presents-final-report-to-minister-alt maier.html [https://perma.cc/87NY-VKDJ].

124. Dig. Competition Expert Panel, Unlocking Digital Competition (2019), https://assets.publishing.service.gov.uk/government/uploads/system/uploads/attachment_data/file/78 5547/unlocking_digital_competition_furman_review_web.pdf [https://perma.cc/G6DH-7F54].

125. Id. at 8 .

126. See OFCOM, supra note 110.

127. Id. ๆ 4.52 . 
reduce rather than enhance competition."128 Accordingly, this report recommends enforcers proceed with care - and not with total hostilityand rigorously analyze the markets and effects at hand, to avoid making such mistakes. ${ }^{129}$

These are by no means the only voices in the debate. There are others advocating against the inhospitality tradition, as developed further below. But as this discussion elucidates, skepticism and calls for an inhospitalitybased approach to big tech have grown quite loud today.

\section{IS THERE A BIG TECH MARKET FAILURE?}

While the inhospitality-style arguments are particularly cacophonous today, they are by no means new - even in the modern era. Not that long ago, there were allegations that companies from $\mathrm{AOL}^{130}$ to $\mathrm{MySpace}^{131}$ to Walmart ${ }^{132}$ were the insurmountable monopolists commanding and controlling their respective markets. The ubiquity of at least two of these firms has decreased precipitously over the last several years - and none are the primary focus of the current debate. And perhaps therein lies important lessons for today.

Before delving into an examination of whether the calls to return to the inhospitality tradition are warranted, it is important to identify the critical first question: Is there evidence of a market failure? This threshold issue must be confronted when attempting to understand whether and when intervention may be warranted. Absent a market failure, there is no value-add for antitrust enforcement. ${ }^{133}$ In other words, if competition is

128. Id. 95.16

129. Id. $₫ 5.17$.

130. See, e.g., AOL's Instant Messaging Monopoly?, WIRED (Dec. 26, 2000, 2:00 AM), https:// www.wired.com/2000/12/aols-instant-messaging-monopoly/ [https://perma.cc/4GCK-RREK]; Joe Salkowski, AOL May Also Have Monopoly, CHI. TRIB. (June 19, 2000), https://www.chicagotribune .com/news/ct-xpm-2000-06-19-0006190010-story.html [https://perma.cc/7FP9-6S7S].

131. See, e.g., Victor Keegan, Will MySpace Ever Lose Its Monopoly?, GUARDIAN (Feb. 8, 2007, 7:41 AM), https://www.theguardian.com/technology/2007/feb/08/business.comment [https://perma .cc/9RMW-GWEM].

132. See, e.g., Barry C. Lynn, The Case for Breaking Up Walmart, ForeIGN POL'Y (Apr. 29, 2013, 3:00 AM), https://foreignpolicy.com/2013/04/29/the-case-for-breaking-up-walmart/ [https://perma .cc/3RLT-ZJXY].

133. Note that, even the presence of a market failure alone is not sufficient for government action; it should also be demonstrated that the benefits of government action would outweigh the costs. See, e.g., Exec. Order No. 12,866, 58 Fed. Reg. 51,735 (Sept. 30, 1993) ("The American people deserve a regulatory system that works for them, not against them: a regulatory system that protects and improves their health, safety, environment, and well-being and improves the performance of the economy without imposing unacceptable or unreasonable costs on society.... Federal agencies should promulgate only such regulations as are ... made necessary by compelling public need, such as material failures of private markets ...."); R.H. Coase, The Problem of Social Cost, 56 J.L. \& 
functioning as it should, then increasing or changing how antitrust regulates the underlying market would not improve upon the status quo.

To understand whether there is, in fact, a market failure, requires an understanding of the empirical effects of firm behavior in the big-tech space. While the critics and reports cited above attempt thoroughly to consider the potential theories by which big tech firms may be harming competition, they have yet to identify any systematic, or other empirical, evidence that anticompetitive effects are manifesting. A focus on empirics is critical-particularly when calls to alter the foundational rules governing industries are under consideration-because, as Judge Easterbrook has explained:

[T] he world of economic theory is full of "existence theorems"-proofs that under certain conditions ordinarily-beneficial practices could have undesirable consequences. But we cannot live by existence theorems. The costs of searching for these undesirable examples are high. The costs of deterring beneficial conduct (a byproduct of any search for the undesirable examples) are high. ${ }^{134}$

That is, existence theorems are not, and cannot be, sufficient to justify legal action. Existence theorems may or may not bear out in the real world. And so action based upon such theorems may or may not benefit consumers. Consumers deserve better than "maybe," particularly when that maybe comes - as it must - at a cost to them. ${ }^{135}$

To avoid basing a - potentially incredibly costly — regulatory regime upon existence theorems rather than upon reality, and to avoid falling victim to over-and erroneous-reliance upon monopoly explanations, we must rigorously examine the empirics and act only when real-world evidence suggests doing so will benefit consumers. This Part reviews the empirical literature examining the consumer welfare effects in big tech and of vertical arrangements, as well as the implications of these literatures.

ECON. 837, 853 (2013) [hereinafter Coase, Problem of Social Cost] (republishing the original article, first published in 1960) ("All solutions have costs and there is no reason to suppose that government regulation is called for simply because the problem is not well handled by the market or the firm. Satisfactory views on policy can come only come from a patient study of how, in practice, the market, firms and governments handle the problem of harmful effects .... It is my belief that economists, and policy-makers generally, have tended to over-estimate the advantages which come from governmental regulation.").

134. Easterbrook, supra note 24, at 15 .

135. Any government action comes with costs, which consumers (or taxpayers) fund. Correctly stopping harmful conduct may be worth that cost; but incorrectly condemning conduct is almost certainly not. 


\section{A. Consumer Welfare Effects in Big Tech}

Thus far in the debate, critics have focused primarily upon articulating the possible theories that could underpin antitrust liability. ${ }^{136}$ These efforts have been thoughtful and comprehensive. It is important for regulators and other experts to consider what theories may be at play, particularly in novel or innovative markets, where such harms may not be self-evident.

However, the efforts so far have failed in a respect critical to enforcers: that is, they often jump from the identified existence theorems to proposed remedies without empirical evidence to corroborate their theorems. This jump is particularly problematic when the remedies proposed are not focused to a specific instance of alleged harm, but rather would alter the fundamental legal responsibilities and liabilities of firms in a given industry.

The critics' arguments and reports largely advocate for a return to the inhospitality tradition, ${ }^{137}$ but what does the evidence actually support? There has been some very important, interesting work examining consumer welfare in the big tech space. Erik Brynjolfsson and his coauthors, for instance, have deployed "massive online choice experiments to measure changes in [consumer] well-being."138 Their efforts attempt to measure consumer surplus deriving from various big tech products and services. ${ }^{139}$ As they explain, consumer surplus may be a better measure of effects because, in this space, goods and services are often discounted or even zero-price. ${ }^{140}$ GDP and other productivity statistics that rely upon consumer prices fail to capture the value of such goods and services, and so they tend to misestimate actual well-being. ${ }^{141}$ Indeed, Brynjolfsson and his coauthors "find that digital goods generate a large amount of consumer welfare that is currently not captured in GDP." 142

Their experiments estimate willingness to accept (WTA) valuations, that is, the monetary value needed to compensate consumers for their loss

\footnotetext{
136. See supra Part II.

137. Id.

138. Erik Brynjolfsson et al., Using Massive Online Choice Experiments to Measure Changes in Well-Being, 116 PNAS 7250, 7250 (2019) [hereinafter Brynjolfsson et al., Using Massive Online Choice Experiments]; see also Erik Brynjolfsson et al., GDP-B: Accounting for the Value of New and Free Goods in the Digital Economy 2-6 (Nat'l Bureau of Econ. Research, Working Paper No. 25695, 2019), https://www.gwern.net/docs/economics/2019-brynjolfsson.pdf [https://perma.cc/7UWPHGJE] (expanding on Massive Online Choice Experiments to determine Facebook's impact on welfare growth).

139. See sources cited supra note 138.

140. See Brynjolfsson et al., Using Massive Online Choice Experiments, supra note 138, at 7250.

141. Id.

142. Id.
} 
of access to various goods. ${ }^{143}$ As demonstrated in Table 1 below, consumers' WTA valuations for various online goods and services are significant. $^{144}$ For instance, in 2017 consumers would demand over $\$ 17,500$ to lose access to search engines for one year; and they would demand well over $\$ 1,100$ to lose access to video services per year. ${ }^{145}$ As the authors note, consumers tend to pay only about $\$ 120$ to $\$ 240$ per year for access to online video services - so their measure indicates "the surplus the median consumers receive from these goods is a 5 to 10 multiple of what they actually pay."146 These measures suggest the consumer surplus deriving from various digital services is remarkable.

\begin{tabular}{|c|c|c|c|c|c|c|c|}
\hline \multirow[b]{2}{*}{ Category } & \multirow{2}{*}{$\begin{array}{c}\text { WTA per year } \\
2016, \$\end{array}$} & \multirow{2}{*}{$\begin{array}{c}\text { WTA per year } \\
2017, \$\end{array}$} & \multicolumn{2}{|c|}{$\begin{array}{c}95 \% \mathrm{Cl} \text { WTA } \\
\text { per year 2016, \$ }\end{array}$} & \multicolumn{2}{|c|}{$\begin{array}{c}95 \% \mathrm{Cl} \text { WTA } \\
\text { per year 2017, \$ }\end{array}$} & \multirow[b]{2}{*}{$n$} \\
\hline & & & Lower & Upper & Lower & Upper & \\
\hline All search engines & 14,760 & 17,530 & 11,211 & 19,332 & 13,947 & 22,080 & 8,074 \\
\hline All email & 6,139 & 8,414 & 4,844 & 7,898 & 6,886 & 10,218 & 9,102 \\
\hline All maps & 2,693 & 3,648 & 1,897 & 3,930 & 2,687 & 5,051 & 7,515 \\
\hline All video & 991 & 1,173 & 813 & 1,203 & 940 & 1,490 & 11,092 \\
\hline All e-commerce & 634 & 842 & 540 & 751 & 700 & 1,020 & 11,051 \\
\hline All social media & 205 & 322 & 156 & 272 & 240 & 432 & 6,023 \\
\hline All messaging & 135 & 155 & 98 & 186 & 114 & 210 & 6,076 \\
\hline All music & 140 & 168 & 112 & 173 & 129 & 217 & 6,007 \\
\hline
\end{tabular}

Other empirical work tends to support these impressive findings. For instance, a 2019 National Bureau of Economic Research (NBER) working paper found the "median and mean willingness-to-accept to deactivate Facebook for weeks 1-4 were $\$ 100$ and $\$ 180$, respectively." 147 It further found that "[m]ultiplying the mean by the approximately 172 million US Facebook users ... impl[ied] that 27 days of Facebook generates $\$ 31$ billion of consumer surplus." 148 Another study estimated that, even using the "most conservative of [its] mean WTA estimates, if applied to Facebook's 214 million U.S. users, suggest[ed] an annual value of over \$240 billion to users." ${ }^{449}$ Similarly, a 2016 NBER working paper used nearly 50 million individual-level observations from four U.S. cities and regression analysis to examine the effects of Uber. ${ }^{150}$ It found that in 2015,

143. Id. at 7251 .

144. Id. at 7252 tbl.1.

145. Id.

146. Id. at 7252

147. Hunt Allcott et al., The Welfare Effects of Social Media 5 (Nat'1 Bureau of Econ. Research, Working Paper No. 25514, 2019).

148. Id. at 32 .

149. Jay R. Corrigan et al., How Much Is Social Media Worth? Estimating the Value of Facebook by Paying Users to Stop Using It, 13 PLOS ONE, Dec. 2018, at 1, 7.

150. Peter Cohen et al., Using Big Data to Estimate Consumer Surplus: The Case of Uber 4 (Nat'1 
alone, the UberX service generated nearly $\$ 2.9$ billion in consumer surplus in just those cities - and that a rough calculation implied "that the overall consumer surplus generated by the UberX service in the United States in 2015 was $\$ 6.8$ billion." 151

Even earlier empirical analyses of (comparatively) modest developments in digital goods and services produce astounding estimates of consumer surplus. Here again, Brynjolfsson and his coauthors offer valuable insights. They conducted a study to analyze the "economic impact of increased product variety" that online sellers made possible. ${ }^{152}$ While they acknowledge that efficiency gains from increased competition such websites might provide itself contributed to consumer surplus, their "research show[ed] that increased product variety made available through electronic markets can be a significantly larger source of consumer surplus gains." "153 They note the number of different books available on Amazon at the time was more than twenty-three times larger than the number on the shelves at a typical Barnes \& Noble, and about fifty-seven times greater than the number of books in a typical large, independent bookstore. ${ }^{154}$ Analyzing the "increased product variety of online bookstores," they found this increase "enhanced consumer welfare by $\$ 731$ million to $\$ 1.03$ billion in the year 2000, which [was] between 7 and 10 times as large as the consumer welfare gain from increased competition and lower prices in this market." ${ }^{155}$ And an earlier study analyzing the value of broadband found that "[c]onsumers receive more than $\$ 30$ billion of net benefits from the use of fixed-line broadband at home." 156

To the extent modern criticisms focus upon alleged effects to inequality or democracy - which many do ${ }^{157}$ - other empirical studies demonstrate the disproportionate benefits that can flow to less wealthy consumers when businesses offer lower prices and easier access. Jason

\footnotetext{
Bureau of Econ. Research, Working Paper No. 22627, 2016), https://www.nber.org/papers /w22627.pdf [https://perma.cc/S5KV-55BN].

151. Id. at 16 .

152. Erik Brynjolfsson et al., Consumer Surplus in the Digital Economy: Estimating the Value of Increased Product Variety at Online Booksellers, 49 MGMT. SCI. 1580, 1580 (2003).

153. Id.

154. Id.

155. Id.

156. Mark Dutz et al., The Substantial Consumer Benefits of Broadband Connectivity for U.S. Households, COMPASS LEXECON (July 2009), https://www.compasslexecon.com/wp-content /uploads/2018/04/Consumer_benefits_of_Broadband.pdf [https://perma.cc/3CGM-VWTQ].

157. See, e.g., Warren, supra note 6 ("Today's big tech companies have too much power- too much power over our economy, our society, and our democracy."); Khan supra note 7, at 767 \& throughout (discussing the "political risks associated with Amazon's market dominance"); Khan \& Vaheesan, supra note 6, at 238 (arguing that modern antitrust enforcement "has permitted large corporations to dominate our markets and politics" and contributed to economic inequality).
} 
Furman, for instance, examined the effects of Wal-Mart on U.S. households. ${ }^{158}$ He found that "[p]lausible estimates of the magnitude of the savings from Wal-Mart are enormous - a total of $\$ 263$ billion in 2004, or $\$ 2,329$ per household." 159 Moreover, he noted that lower-income households disproportionately benefit from the presence of Wal-Mart, as demonstrated in the table below. ${ }^{160}$ Because families with lower incomes devote higher percentages of their income to staples, like food, than higher income families, they benefit more from being able to purchase lowerpriced food at Wal-Mart. ${ }^{161}$

\begin{tabular}{|c|c|c|c|c|c|}
\hline \multicolumn{7}{|c|}{ Table 1. Benefits for Food Consumers } \\
\hline & $\begin{array}{c}\text { Income } \\
\text { pre-tax) }\end{array}$ & $\begin{array}{c}\text { Food At } \\
\text { Home }\end{array}$ & $\begin{array}{c}\text { Food } \\
\text { Share of } \\
\text { Income }\end{array}$ & $\begin{array}{c}\text { Total } \\
\text { Welfare } \\
\text { Increase }\end{array}$ & $\begin{array}{c}\text { Welfare } \\
\text { Increase } \\
(\% \text { of } \\
\text { Income })\end{array}$ \\
\hline Bottom Quintile & $\$ 8,201$ & $\$ 2,119$ & $25.8 \%$ & $\$ 530$ & $6.5 \%$ \\
\hline Second Quintile & $\$ 21,478$ & $\$ 2,713$ & $12.6 \%$ & $\$ 678$ & $3.2 \%$ \\
\hline Third Quintile & $\$ 37,542$ & $\$ 3,114$ & $8.3 \%$ & $\$ 779$ & $2.1 \%$ \\
\hline Fourth Quintile & $\$ 61,132$ & $\$ 3,726$ & $6.1 \%$ & $\$ 932$ & $1.5 \%$ \\
\hline Top Quintile & $\$ 127,146$ & $\$ 4,503$ & $3.5 \%$ & $\$ 1,126$ & $0.9 \%$ \\
\hline All & $\$ 51,128$ & $\$ 3,129$ & $\mathbf{6 . 1 \%}$ & $\$ \mathbf{7 8 2}$ & $\mathbf{1 . 5 \%}$ \\
\hline
\end{tabular}

Source: Data from Bureau of Labor Statistics, June 2005, Consumer Expenditures in 2003 and author's calculations.

One might imagine that digital products and services - like search engines, email, and ecommerce-which often offer increased product variety, lower prices, increased ease of use (i.e., less time consumers must devote to accomplishing their goals) - would likewise disproportionately benefit those most sensitive to price and leisure-time constraints. Risking these benefits by fundamentally altering the legal framework governing the companies from which these benefits derive could, then, be extremely costly to those who can least afford it.

These and other studies strongly demonstrate that digital markets are - and have been for several years-yielding significant consumer benefits. Of course, these findings do not indicate that such markets are entirely free from anticompetitive activity. But they do suggest a very different starting point than advocates of a new inhospitality tradition

158. Jason Furman, Wal-Mart: A Progressive Success Story 1 (2005), https://www.mackinac.org /archives/2006/walmart.pdf [https://perma.cc/EZX2-GH8V].

159. Id.

160. Id. at 3 tbl.1.

161. Id. at 3. Furman also notes that, "Even if you grant that Wal-Mart hurts workers in the retail sector - and the evidence for this is far from clear - the magnitude of any potential harm is small in comparison [to the estimated $\$ 263$ billion benefits in 2004]. One study, for example, found that the 'Wal-Mart effect' lowered retail wages by $\$ 4.7$ billion in 2000." Id. at 1. This reduction is wages represents less than $2 \%$ of the benefits Furman estimates. 
would seem to accept. The immense consumer benefits strongly indicate these markets have remained incredibly competitive and valuable sources of consumer welfare for decades. It is always possible that consumer welfare benefits would be even greater if certain, allegedly anticompetitive, conduct were not present. But that is a very different argument - and suggests a very different set of remedies - than a new inhospitality tradition would embrace.

\section{B. Consumer Welfare Effects of Vertical Arrangements}

Vertical integration has been one of the more frequently empirically investigated phenomena in modern industrial organization. Vertical integration and expansion are not new. The existence of such conduct is essentially coextensive with the existence of firms themselves. ${ }^{162}$ So long as there have been firms, they have tried to discern new ways to serve consumer demand - which invariably entails vertical growth of some sort.

Even "self-preferencing" or "discrimination" is not new. It is a common business model for brick-and-mortar stores to sell their own private label (or generic) brands alongside brand-name products (recall Topco). ${ }^{163}$ These businesses often offer their own products to consumers at lower, more favorable prices than brand-names - after all, they have the information regarding what brands will charge and can adapt their prices accordingly. Moreover, they often favor their own products in-store: they tend to give preferential shelf space to their own products and to flag their products with brightly colored advertisements showcasing their comparability to the brand-name products and their lower prices. ${ }^{164}$ Economists have studied this behavior extensively, and-as with the benefits of vertical integration the Supreme Court has frequently acknowledged $^{165}$-recognized that this conduct frequently has potential procompetitive rationales. ${ }^{166}$ Brick-and-mortar stores have even found

162. See Ronald H. Coase, The Nature of the Firm, 4 ECONOMICA 386, 397-98 \& n.5 (1937).

163. See United States v. Topco Assocs., Inc., 405 U.S. 596 (1972).

164. Benjamin Klein \& Joshua D. Wright, The Economics of Slotting Contracts, 50 J.L. \& ECON. 421, 426-27 (2007).

165. See, e.g., Leegin Creative Leather Prods., Inc. v. PSKS, Inc., 551 U.S. 877, 899 (2007); Bus. Elecs., Corp. v. Sharp Elecs. Corp., 485 U.S. 717, 735-36 (1988); Cont'1 Television, Inc. v. GTE Sylvania, Inc., 433 U.S. 36, 51, 55-56 (1977).

166. See, e.g., Coase, The Nature of the Firm, supra note 162, at 388-89; R.H. Coase, Industrial Organization: A Proposal for Research, in 3 ECONOMIC RESEARCH: RETROSPECT AND PROSPECT (Victor R. Fuchs ed., 1972); Oliver E. Williamson, The Vertical Integration Production: Market Failure Considerations, 61 AM. ECON. REV. 112, 118 (1971); Benjamin Klein et al., Vertical Integration, Appropriable Rents, and the Competitive Contracting Process, 21 J.L. \& ECON. 297, 324 (1978); Benjamin Klein \& Kevin M. Murphy, Vertical Integration As a Self-Enforcing Contractual 
ways to incorporate such favorable treatment into their online stores. For instance, searches for "ibuprofen" of CVS's website tend to return results first for CVS's store brand variety, followed by brand-name offerings. ${ }^{167}$ In the online space, available empirical evidence tends to suggest that selfpreferencing is likewise not the result of, or an abuse of, market power; but instead, like its real-world counterparts, tends to represent efforts by firms to better satisfy consumer demands. ${ }^{168}$

Perhaps unsurprisingly, given the ubiquity of vertical arrangements, numerous economists have devoted several studies (and meta-studies) to enhancing our understanding of how vertical arrangements affect consumer welfare. These studies repeatedly find that vertical arrangements tend to be procompetitive or competitively neutral. ${ }^{169}$

Arrangement, 87 AM. ECON. REV. 415, 415-16 (1997); Benjamin Klein, Fisher-General Motors and the Nature of the Firm, 43 J.L. \& ECON. 105, 115-17 (2000); Klein \& Wright, supra note 164, at 42627; Alden F. Abbott \& Joshua D. Wright, Antitrust Analysis of Tying Arrangements and Exclusive Dealing, in ANTITRUST LAW AND ECONOMICS 183 (Keith N. Hylton ed., 2d ed. 2010); see also Timothy Bresnahan \& Jonathan Levin, Vertical Integration and Market Structure, in HANDBOOK OF ORgANIZATIONAL ECONOMICS (Robert Gibbons \& John Roberts eds., 2012) (summarizing the literature).

167. Searches for over-the-counter pharmaceutical drugs provide particularly good points of comparison because, by definition, the generic and brand-name products will be the same.

168. See, e.g., Joshua D. Wright, Moving Beyond Naïve Foreclosure Analysis, 19 GEO. MASON L. ReV. 1163, 1193-97 (2012); Joshua D. Wright, Defining and Measuring Search Bias: Some Preliminary Evidence 2 (Geo. Mason L. \& Econ. Research Paper Series, Paper No. 12-14, 2011); Statement of the Federal Trade Commission Regarding Google's Search Practices, In re Google Inc., FTC File No. 111-0163, at 3 (Jan. 3, 2013), https:/www.ftc.gov/sites/default/files/documents/public _statements/statement-commission-regarding-googles-search-practices/130103brillgooglesearchstmt .pdf [https://perma.cc/V86J-3M2N] (explaining that it found no evidence Google's alleged "search bias" had harmed consumers because, while some websites that could be considered competitors to Google were demoted, "[o]n the other hand, these changes to Google's search algorithm could reasonably be viewed as improving the overall quality of Google's search results because the first search page now presented the user with a greater diversity of websites").

169. See, e.g., Glob. Antitrust Inst., Antonin Scalia Law Sch., Comment Submitted in the Federal Trade Commission's Hearings on Competition and Consumer Protection in the 21st Century, Vertical Mergers 8 (Sept. 6, 2018), https://gai.gmu.edu/wp-content/uploads/sites/27/2018/09/GAI-Comment -on-Vertical-Mergers.pdf [https://perma.cc/8VM2-VE78] [hereinafter GAI Comment 2018] ("In sum, these papers from 2009-2018 continue to support the conclusions from Lafontaine \& Slade (2007) and Cooper et al. (2005) that consumers mostly benefit from vertical integration. While vertical integration can certainly foreclose rivals in theory, there is only limited empirical evidence supporting that finding in real markets."); Glob. Antitrust Inst., Antonin Scalia Law Sch., Comment on DOJ/FTC Draft 2020 Vertical Merger Guidelines 14 [hereinafter GAI Comment 2020] (updating that analysis); Francine Lafontaine \& Margaret Slade, Exclusive Contracts and Vertical Restraints: Empirical Evidence and Public Policy, in HANDBOOK OF AnTITRUST ECONOMICs 391, 409 (Paolo Buccirossi ed., 2008) ("[I]t appears that when manufacturers choose to impose such [vertical] restraints, not only do they make themselves better off but they also typically allow consumers to benefit from higher quality products and better service provision.”); Francine Lafontaine \& Margaret Slade, Vertical Integration and Firm Boundaries: The Evidence, 45 J. ECON. LITERATURE 629, 677 (2007) [hereinafter Lafontaine \& Slade, Vertical Integration] ("The data appear to be telling us that efficiency considerations overwhelm anticompetitive motives in most contexts. Furthermore, even when we limit attention to natural monopolies or tight oligopolies, the evidence of anticompetitive harm is not strong."); Daniel P. 
Francine Lafontaine and Margaret Slade, for instance, conducted a metaanalysis of dozens of empirical studies published between the 1960s and 2000s. ${ }^{170}$ They found compelling evidence that "under most circumstances, profit-maximizing vertical-integration decisions are efficient, not just from the firms' but also from the consumers' points of view." "Their review found only "isolated studies that contradict[ed] this claim," while the "vast majority support[ed] it."

Lafontaine and Slade's analysis yielded two additional insights critical to the current discussion. First, they found that "even in industries that are highly concentrated ... the net effect of vertical integration appears to be positive in many instances." 173 And second, they found "clear evidence that restrictions on vertical integration... are usually detrimental to consumers." 174 Indeed, they note that "consumers are often worse off when governments require vertical separation in markets where firms would have chosen otherwise." ${ }^{175}$ This would seem to present a strong caution against ill-conceived government intervention.

Similarly, several current and former antitrust enforcers-James Cooper, Luke Froeb, Dan O’Brien, and Michael Vita—reviewed several empirical pieces on vertical restraints and vertical integration. ${ }^{176}$ They found "two features immediately st[oo]d out: First, there is a paucity of support for the proposition that vertical restraints/vertical integration are

O'Brien, The Antitrust Treatment of Vertical Restraints: Beyond the Possibility Theorems, in THE PROS AND CONS OF VERTICAL RESTRAINTS 40, 76 (2008) ("With few exceptions, the literature does not support the view that these [vertical integration] practices are used for anticompetitive reasons. This literature supports a fairly strong prior belief that these practices are unlikely to be anticompetitive in most cases.").

170. See generally Lafontaine \& Slade, Vertical Integration, supra note 169.

171. Id. at 680 .

172. Id.

173. Id.

174. Id.

175. Id. at 663 .

176. Cooper et al., supra note 66. Cooper has held multiple positions at the FTC, including Deputy Director for Economic Analysis in the FTC's Bureau of Consumer Protection, and Deputy and Acting Director of the FTC's Office of Policy Planning. See Dr. James C. Cooper, FEDERALIST SoC'Y, https://fedsoc.org/contributors/james-c-cooper [https://perma.cc/4X4W-76TU] (last visited Apr. 8, 2020). Froeb recently served as Deputy Assistant Attorney General at the U.S. Department of Justice, Antitrust Division; he also served as Director of the Bureau of Economics at the FTC. See Division Update Spring 2018, U.S. DEP'T OF JUSTICE (Apr. 2018), https://www.justice.gov/atr/divisionoperations/division-update-spring-2018/meet-front-office [https://perma.cc/B9JC-JWR6]. O'Brien is "a former Senior Economic Policy Adviser and Deputy Director of the [FTC]'s Bureau of Economics, and former Chief of the Economic Regulatory Section at the Department of Justice's Antitrust Division." See Daniel P. O'Brien, COMPASS LEXICON, https://www.compasslexecon.com /professionals/daniel-p-obrien/ [https://perma.cc/97PS-ZUX5] (last visited Apr. 8, 2020). Vita is Deputy Director of the FTC's Bureau of Economics. See Michael G. Vita, FED. Trade COMM'N, https://www.ftc.gov/about-ftc/biographies/michael-g-vita [https://perma.cc/47AJ-VL5B] (last visited Apr. 8, 2020). 
likely to harm consumers.... Second, a far greater number of studies found that the use of vertical restraints in the particular context studied improved welfare unambiguously (i.e., resulted in lower prices and larger quantities)." ${ }^{177}$ The Global Antitrust Institute recently updated the empirical literature reviews, to similar result. ${ }^{178}$ Its review examined about a dozen empirical studies released between 2008 and 2018, concluding that "recent empirical evidence continues to support the proposition that vertical integration generates abundant efficiencies and is generally procompetitive." 179

Some criticisms today focus upon the shortcomings in the empirical literature. There is no doubt that determining the consumer welfare effects of the conduct under examination can be difficult. But the body of literature, as a whole, presents a compelling case. ${ }^{180}$ Other criticisms rely heavily upon the studies finding harm to consumer welfare, arguing that recent empirical work indicates harm manifests more often than enforcers suppose, and that this work supports a change to current law enforcement approaches. ${ }^{181}$ But, as discussed, recent reviews of the empirical literature continue to support the belief that harmful outcomes are exceptions to the weight of the empirical literature. ${ }^{182}$ If the choice is between basing policy on a healthy skepticism and wholistic view of the empirical literature, or dismissing the substantial literature and relying instead upon fears that the bulk of the literature does not support, the better policy approach seems clear. Moreover, such exceptions suggest, at most, marginally more vertical arrangements should be challenged. They do not warrant prohibiting or presuming such arrangements to be unlawful.

Accordingly, the existing empirical literature on vertical arrangements poses very real challenges to adopting the inhospitality approach in big tech. First, the weight of the empirical literature demonstrates most

177. Cooper et al., supra note 66 , at 648.

178. GAI Comment 2018, supra note 170, at 5-9 ("In sum, these papers from 2009-2018 continue to support the conclusions from Lafontaine \& Slade (2007) and Cooper et al. (2005) that consumers mostly benefit from vertical integration.").

179. Id. at 12; see also GAI Comment 2020, supra note 170, at 14 ("While vertical integration can certainly foreclose rivals in theory, there is only limited empirical evidence supporting that finding in real markets."). GAI originally identified thirteen studies, eleven of which allowed inferences regarding welfare effects. Id. at 6-7. GAI later removed one study because "it did not involve a vertical component to the examined merger." Id. at 12 n.30.

180. Lafontaine \& Slade, Vertical Integration, supra note 169, at 631 ("Since those issues are not always dealt with satisfactorily, one can be skeptical about some of the conclusions that authors have reached. Nevertheless, taken as a body, the evidence is often so strong that it can overcome much of our skepticism.").

181. See Salop, supra note 109, at 1987 n.103.

182. See GAI Comment 2018, supra note 169, at 12; see also GAI Comment 2020, supra note 169 , at 17 ("[T] he proposed VMGs reject presumptions of illegality or legality in favor of a case-bycase approach."). 
vertical arrangements will benefit (or at least not harm) consumers. ${ }^{183}$ The policy implications of these findings are - as the authors of the literature reviews have repeatedly acknowledged - that antitrust enforcers should continue to bear the burden to prove harm is likely in the cases in which they seek to act. ${ }^{184}$ Shifting the foundation of the antitrust laws to tilt against arrangements that tend to yield consumer benefits would eliminate significant consumer value without significant countervailing benefits. ${ }^{185}$

Second, we do not have a robust framework to identify ex ante which vertical arrangements are among the rare ones likely to harm competition, and which fall into the broader category of being procompetitive or competitively neutral. Empirical evidence does not provide clear insights. And theory on the likely effects of vertical arrangements likewise fails to provide decisive guidance. The very same factors that make foreclosure more likely (such as market power) also tend to make efficiencies more likely. Lafontaine and Slade's analysis demonstrated that even in highly concentrated industries (i.e., industries where market power is likely present), positive welfare effects were frequently observed. ${ }^{186}$ Many of the arguments in favor of condemning vertical arrangements in the big tech space today rely upon the alleged existence of market power-but here again, the empirical evidence fails to suggest that the presence of market power, alone, is a sufficient basis to condemn vertical relationships. ${ }^{187}$ Given the state of both the theoretical literature-which cannot predict ex ante which arrangements will likely be harmful-and the empirical literature - which suggests harmful results are quite rare - there remains no compelling basis for adopting rules that would categorically eliminate

183. See, e.g., GAI Comment 2018, supra note 169, at 5-9.

184. Lafontaine \& Slade, Vertical Integration, supra note 169 at 680 ("We therefore conclude that, faced with a vertical arrangement, the burden of evidence should be placed on competition authorities to demonstrate that that arrangement is harmful before the practice is attacked."); see also GAI Comment 2020, supra note 169, at 14 ("The results continue to suggest that the modern antitrust approach to vertical mergers should reflect the empirical reality that vertical relationships are generally procompetitive or neutral."); GAI Comment 2018, supra note 169, at 8-9 (same); Cooper et al., supra note 66, at 639 ("Thus, absent a good natural experiment to evaluate a particular restraint's effect, an optimal policy places a heavy burden on plaintiffs to show that a restraint is anticompetitive."); O'Brien, supra note 169 at 82 ("Thus, my own view, based largely on a Hippocratic philosophy of non-intervention absent good evidence that intervention will have benefits, is that direct evidence of likely harm should be required before condemning a vertical practice. If there were a Hippocratic Oath among antitrust practitioners, this is where a scientific approach would lead.").

185. Even for those vertical contracts that studies deemed competitively neutral might very well have some benefits to the economy, as a whole. For instance, if a vertically integrated firm is able to lower its costs, even if those lower costs are not directly passed on to consumers, they are real nonetheless and have positive benefits somewhere (without any harm to consumers).

186. Lafontaine \& Slade, Vertical Integration, supra note 169, at 680 ("[E]ven in industries that are highly concentrated so that horizontal considerations assume substantial importance, the net effect of vertical integration appears to be positive in many industries.").

187. See sources cited supra note 169. 
or presumptively condemn vertical arrangements.

Third, the empirical evidence to date fails to demonstrate, or even to suggest, that vertical arrangements in the big tech space are more likely to yield harmful effects than they are in any other industry. In other words, the empirical literature today does not support the notion that we should be any more skeptical of vertical arrangements in the big tech space than in any other space. In turn, this again underscores that enforcers have no sound, empirical basis for establishing different laws, standards, or presumptions regarding vertical arrangements in the big tech space today.

\section{SOONER OR LATER I'M GREATER THAN YOU ${ }^{188}$}

The drive to be the best, to be the market leader, to command a presence that competitors cannot ignore, is critical to the proper functioning of the American economy. The inhospitality approach undermined this very drive, and was abandoned in response. But today, the inhospitality approach threatens a resurgence, particularly with respect to vertical (or nonhorizontal) growth. Such a resurgence portends significant losses to consumer welfare, both directly-as vertical arrangements that would benefit consumers are no longer realized-and indirectly — as the competitive pressures that such arrangements would introduce are not realized, either. The latter, losses to indirect, dynamic competition, may be especially costly to consumers. This Part considers a case example that would be directly impacted by a new inhospitality approach in big tech - the "streaming wars"-before turning to final considerations of the analysis presented in this Article and how best to preserve the competitive drive that is critical to our economy.

\section{A. The Streaming Wars: A Case Example of Vertical Competition and Big Tech}

The discussion in this Article so far has abstained from engaging in an examination of just how competitive firms in the big tech space may bethat is, how aggressively they are competing on the merits to innovate and to better anticipate and satisfy customer demands. Any thorough analysis is outside the scope of this Article. But before concluding, a bit of anecdotal analysis can provide some insights and help to elucidate the very real consumer benefits that are at play-and which are often lost in the discussion presented by those adopting a more hostile approach.

A very recent example of competition driven in no small part by

188. Berlin, supra note 1 
vertical arrangements and big tech is the so-called streaming wars, which has come to denote the rapidly increasing competitive pressure among services offering streaming for television and movies. As The Verge reported: "The planned launch of Disney+ in November 2019 is ushering in a whole new era of streaming, one where established industry leaders like Netflix, Hulu, HBO Go, and Amazon Prime Video are facing growing competition from major new players in the industry." "189 What is interesting about the streaming wars for the current discussion is that it involves a tremendous amount of vertical repositioning and other vertical arrangements. Cable, telecom, and broadcast television companies like Comcast and NBCUniversal (Peacock), ${ }^{190}$ Cox, AT\&T TimeWarner, and CBS are all positioning to compete-in some cases entering into vertical arrangements to facilitate this positioning. ${ }^{191}$ Incumbents like HBO are repositioning in response. ${ }^{192}$ Others are expanding their offerings: CBS All Access recently added content available only on its app; ESPN + offers exclusive content; and PBS Passport offers extended access to public television content. ${ }^{193}$

Big tech companies like Amazon, Apple, and Google are also critical competitive pressures in this space. Amazon launched its first video service in 2006 and has recently ramped up its spending on original

189. Streaming Wars, THE VERGE, https://www.theverge.com/streaming-wars [https://perma.cc /LVU8-76GS] (last visited Apr. 8, 2020); see also Sonia Saraiya, TV Is Dead. Long Live TV, VANITY FAIR (Nov. 13, 2019), https://www.vanityfair.com/hollywood/2019/11/tv-is-dead-long-live-tvdisney-netflix-hbomax-apple [https://perma.cc/84BN-S5KL] ("The Content Wars have reached full pitch, and they're changing television forever.").

190. Julia Alexander, NBC's Peacock Streaming Service Will Launch on July 15th with Three Different Price Tiers, THE VerGe (Jan. 16, 2020, 4:08 PM), https://www.theverge.com/2020/1 $/ 16 / 21068607 /$ nbc-peacock-streaming-service-price-launch-date-ads-universal-comcast-office-harry -potter [https://perma.cc/PTV8-KC9A].

191. See, e.g., Dieter Bohn, The Streaming Wars Have Barely Started and They're Already Exhausting, THE VERGE (Jan. 17, 2020, 7:00 AM), https://www.theverge.com/2020/1/17/21069703 /streaming-wars-peacock-subscription-fatigue-exhaustion-apple-hbo-hulu-netflix-quibi-disney-augh [https://perma.cc/3XRX-7VSM]; Alex Sherman, Disney+ Isn't Really the Beginning of the Streaming Wars-the Next Year Is Just a Warm-Up, CNBC (Nov. 16, 2019, 9:02 AM), https://www.cnbc.com /2019/11/16/disney-plus-streaming-wars-just-warming-up.html [https://perma.cc/D2PG-B3HG].

192. See Nick Perry \& Chris Gates, What Is HBO Max?, Digital Trends (Mar. 3, 2020), https://www.digitaltrends.com/home-theater/what-is-hbo-max/ [https://perma.cc/P2UT-TYHH] ("Competition between streaming services will get even stiff now that AT\&T's WarnerMedia has announced plans to launch the newly dubbed HBO Max.").

193. See John Callaham, CBS All Access Shows: All Current and Future Exclusive Series, ANDROID AUTHORITY (Jan. 30, 2020), https://www.androidauthority.com/cbs-all-access-shows -1022653/ [https://perma.cc/47MN-NKM7]; Nick Hastings, ESPN+: Everything You Need to Know About ESPN's Streaming Service, BuS. INSIDER (Feb. 6, 2020, 8:46 AM), https://www.business insider.com/what-is-espn-plus [https://perma.cc/2RCD-Y9BE]; What Is PBS Passport?, PBS (Mar. 24, 2020, 1:31 PM), https://help.pbs.org/support/solutions/articles/12000043556-what-is-pbs -passport- [https://perma.cc/LG5W-57XE]. 
content. ${ }^{194}$ Apple recently launched its Apple TV Plus product, with its own original content. ${ }^{195}$ Google offers YouTube, with numerous original channels, and YouTube TV for streaming live broadcast television content. ${ }^{196}$

What would the streaming wars look like under an inhospitality tradition? While it is difficult to say precisely, it is almost certainly the case that it would look nothing like what we see today. Depending upon how expansively the new inhospitality approach was embraced, it could prohibit Amazon from offering original content - or from offering video services at all; Apple from introducing its Apple TV Plus product, which also includes original content today; or Google from offering YouTube $\mathrm{TV}$ or otherwise expanding its YouTube services. If applied more broadly, the approach could also prohibit firms like Disney and ESPN, HBO, Comcast and NBCUniversal, and more from expanding their offerings. The new inhospitality approach espouses extreme suspicion of vertical arrangements or growth by "large" or "powerful" firms - and all these firms would seem to fit those categories as proponents define them.

It seems far from certain that, by prohibiting all this repositioning and growth, a new inhospitality approach would foster competition or consumer benefits in this space. To the contrary, it seems likely that this approach could very well have prevented a significant amount of competition - and the commensurate consumer benefits - that we are experiencing today. It is widely recognized, for instance, that Disney+'s entry into the field helped put the "streaming wars" into overdrive. ${ }^{197}$ But a new inhospitality regime would likely have prevented that entry. Moreover, many of the new or expanding services offer original or exclusive content that is considered very high quality - and which, in turn, puts pressure on other streaming services (not to mention on more traditional cable TV and Hollywood studios) to produce better content. Apple TV Plus, for instance, received its first Golden Globe nomination

194. Jason Del Rey, The Making of Amazon Prime, the Internet's Most Successful and Devastating Membership Program, Vox (May 3, 2019, 6:00 AM), https://www.vox.com/recode/2019/5/3 /18511544/amazon-prime-oral-history-jeff-bezos-one-day-shipping [https://perma.cc/63PW-SJJ4]; Eugene Kim, Amazon on Pace to Spend $\$ 7$ Billion on Video and Music Content This Year, According to New Disclosure, CNBC (Apr. 26, 2019, 3:47 PM), https://www.cnbc.com/2019/04/26/amazon-on -pace-to-spend-7-billion-on-video-and-music-content.html [https://perma.cc/LG62-4XB6].

195. Nick Pino et al., Apple TV Plus Cost, Shows, Channels, Devices, and Everything You Need to Know, TECH RADAR (Feb. 14, 2020), https://www.techradar.com/news/apple-tv-plus-cost-review -and-everything-you-need-to-know [https://perma.cc/P75R-WU44].

196. See Josh Levenson \& Simon Cohen, What Is YouTube TV? Here's Everything You Need to Know, DigiTAL TRENDS (Feb. 28, 2020), https://www.digitaltrends.com/home-theater/what-is -youtube-tv/ [https://perma.cc/BB3N-VWB7]; Channels, YouTUBE, https://www.youtube.com/user /YouTube/channels [https://perma.cc/LSX9-H7U2] (last visited Apr. 8, 2020).

197. See, e.g., Streaming Wars, supra note 189. 
just months after launching. ${ }^{198}$ In other words, the "streaming wars" today involve competition not just for the provision of streaming services themselves - driving firms to seek better options for streaming, rendering it faster, with more options like off-line viewing options-but also for content.

A new inhospitality approach would likely hamper all those aspects of competition. This would constitute no small amount of welfare impaired. Recall that recent estimates of the consumer welfare benefits of online video services was a five to ten multiple of what consumers actually paid in 2017, amounting to over $\$ 1,100$ a year per consumer, before the "streaming wars" really even heated up. ${ }^{199}$

\section{B. Preserving Competitive Drives}

Maintaining fierce competition is critical. On that point, at least, all voices in the debate seem to agree. Where the vigorous disagreement arises is with regard to how antitrust policy and enforcement efforts can, in fact, foster that competition. This Article argues that an approach based upon the best available empirical evidence and experience is warrantedand precludes the hostile approach proponents of a new inhospitality tradition would embrace. At this point in our antitrust enforcement journey, we are fortunate to have both empirical studies of industries and behaviors as well as experience with an earlier inhospitality regime upon which to base our policies and decisions.

That mere existence theorems are insufficient bases for sound policy

198. Sarah Perez, Apple TV+ Picks Up First Golden Globe Nominations, While Netflix Leads Across Film and TV, TECHCRUNCH (Dec. 9, 2019, 9:07 AM), https://techcrunch.com/2019/12/09 /apple-tv-picks-up-first-golden-globe-nominations-while-netflix-across-film-and-tv/ [https://perma .cc/9DLH-MZKW].

199. Brynjolfsson et al., Massive Online Choice Experiments, supra note 138, at 7252. 
or enforcement decisions is clear ${ }^{200}$ - and consistent with the case law. ${ }^{201}$ Indeed, when ruling on the merits of cases before them, courts have repeatedly noted that "antitrust theory and speculation cannot trump facts." 202 If we are to embrace the common sense notion that policy and enforcement should be based upon real world evidence, the inhospitality approach to vertical arrangements simply cannot be accepted. As discussed, the empirical literature to date does not support wide-sweeping

200. See, e.g., Easterbrook, supra note 24, at 15 (“[W]e cannot live by existence theorems."); O'Brien, supra note 169, at 81 ("The theoretical literature on vertical practices over the past 25 years has generated numerous possibility theorems regarding the possible effects of vertical practices. However, possibility theorems without more do not provide a good basis for policy."); Margaret E. Slade, The Effects of Vertical Restraints: An Evidence Based Approach, in THE PROS AND CONS OF VERTICAL RESTRAINTS 12, 13 (2008) ("From this brief discussion, it should be clear that economic theory alone cannot determine if [vertical restraints] should be encouraged or discouraged."); Cooper et al., supra note 66, at 662 ("Until theory can be used to determine how likely it is that a restraint will lead to an anticompetitive outcome, it does not give us a way to interpret evidence in most cases."); see also Joe Simons, Chairman, Fed. Trade Comm'n, Prepared Remarks at Hearings on Competition and Consumer Protection in the 21st Century (Sept. 13, 2018), https://www.ftc.gov/system/files /documents/public_statements/1409925/opening_remarks_of_joe_simons_hearingslgeorgetown_sep t2018_0.pdf [https://perma.cc/Y4KA-G938] ("I would rather make policy and enforcement decisions based on the best evidence and analysis - including in particular, empirically grounded economic analysis that enables the analyst to weigh the costs and benefits (broadly defined) to help determine the best approach."); Coase, Problem of Social Cost, supra note 133, at 853 ("Satisfactory views on policy can come only come from a patient study of how, in practice, the market, firms and governments handle the problem of harmful effects."); Joshua D. Wright, Commissioner, Fed. Trade Comm'n, Competition Law Center, Beijing, China: Evidence-Based Antitrust Enforcement in the Technology Sector, at 4-5 (Feb. 23, 2013), https://www.ftc.gov/sites/default/files/documents/public_statements /evidence-based-antitrust-enforcement-technology-sector/130223chinaevidence.pdf [https://perma.cc /5DNB-REZ4] ("We, as antitrust enforcers, are best served by welcoming and even encouraging the development of new theoretical models and tools while also demanding evidence that these models are reliable predictors of actual firm behavior before they are implemented through enforcement actions."); The Nomination of Elena Kagan to Be an Associate Justice of the Supreme Court of the United States, Hearing Before the Committee on the Judiciary, United States Senate, 111th Cong. (2010) (statement of Elena Kagan, nominee, Supreme Court of the United States) ("I think on the one hand it is clear that antitrust law needs to take account of economic theory and economic understandings, but it needs to do so in a careful way and to make sure that it does so in a way that is consistent with the purposes of the antitrust laws, which is to ensure competition, which is, as you say, to be a real charter of economic liberty.").

201. See, e.g., Bell Atl. Corp. v. Twombly, 550 U.S. 544, 557-58 (2007) (holding that, even at the motion to dismiss stage, "mere possibility" is not enough); United States v. Marine Bancorporation, Inc., 418 U.S. 602, 622-23 \& n.22 (1974) ("But it is to be remembered that [Section] 7 [of the Clayton Act] deals in 'probabilities,' not 'ephemeral possibilities." (quoting Brown Shoe v. United States, 370 U.S. 294, 323 (1962))); United States v. Baker Hughes Inc., 908 F.2d 981, 984 (D.C. Cir. 1990) ("Section 7 [of the Clayton Act] involves probabilities.").

202. FTC v. Arch Coal, Inc., 329 F. Supp. 2d 109, 116 (D.D.C. 2004); see also State of N.Y. v. Deutsche Telekom, AG, 19-5434, slip op. at 136 (S.D.N.Y. Feb. 11, 2020) (quoting Arch Coal, 329 F. Supp. 2d at 116-17) (same); FTC v. RAG-Stiftung, No. 19-2337, slip op. at 4 (D.D.C. Feb. 3, 2020) (quoting Arch Coal, 329 F. Supp. 2d at 116-17) (same); FTC v. Tronox Ltd., 332 F. Supp. 3d 187, 197 (D.D.C. 2018) (quoting Arch Coal, 329 F. Supp. 2d at 116) (same); United States v. AT\&T Inc., 310 F. Supp. 3d 161, 190 (D.D.C. 2018) (same) (quoting Arch Coal, 329 F. Supp. 2d at 116-17) (same); FTC v. CCC Holdings Inc., 605 F. Supp. 2d 26, 37 (D.D.C. 2009) (quoting Arch Coal, 329 F. Supp. 2d at 116-17) (same). 
changes to the antitrust law on vertical arrangements. ${ }^{203}$ Neither the literature broadly examining the welfare effects of online or big tech products and services nor the literature analyzing the effects of vertical arrangements suggest that something is fundamentally amiss.

Quite to the contrary, the combined evidence would tend to suggest that rules prohibiting or presumptively condemning vertical arrangements in big tech are not only unwarranted, but are, in fact, likely to destroy significant consumer value. Empirical evidence suggests consumers frequently benefit from vertical arrangements. ${ }^{204}$ And it likewise suggests that consumers broadly benefit from big tech products and services today. Many, if not most, of those benefits would be devastated by a new inhospitality approach.

Moreover, empirical evidence and experience indicates government intervention along the lines of what the new inhospitality tradition would call for is often costly to consumers. For instance, Lafontaine and Slade found "consumers are often worse off when governments require vertical separation in markets where firms would have chosen otherwise." ${ }^{205}$ They further argue, given these findings, that it "behooves government agencies to reconsider the validity of such restrictions." ${ }^{206}$ Similarly, FTC Commissioner Christine Wilson and her Attorney Advisor Keith Klovers recently examined the implications of past regulatory actions for the digital space. ${ }^{207}$ Their analysis documents the many pitfalls — and costs to consumers - of various policies, including banning vertical integration. ${ }^{208}$ From this analysis, they warn that "even the most well-intentioned regulations come at a steep cost." ${ }^{\text {"209 }}$

Proponents of a new inhospitality tradition have failed not only to provide a sound empirical basis for their policy prescriptions in the first instance, but they have likewise failed to consider in any meaningful way the potential costs of implementing their proposals. As noted, regulatory efforts and changes tend to come with very real costs. ${ }^{210}$ These costs

203. See supra Section III.B.

204. See, e.g., sources cited supra note 169.

205. Lafontaine \& Slade, Vertical Integration, supra note 169, at 663; see also id. at 680 ("[W]e have found clear evidence that restrictions on vertical integration that are imposed ... on owners of retail networks are usually detrimental to consumers.").

206. Id. at 680 .

207. See Christine S. Wilson \& Keith Klovers, The Growing Nostalgia for Past Regulatory Misadventures and the Risk of Repeating These Mistakes with Big Tech, 8 J. ANTITRUST ENFORCEMENT 10 (Nov. 7, 2019).

208. See id. at 16-18 ("All sides soon realized how economically damaging such a ban would be.").

209. Id. at 26 .

210. See id.; Lafontaine \& Slade, Vertical Integration, supra note 169, at 680; see also sources cited supra note 169. 
include a real dampening of the dynamic competition that drives firms to expand to satisfy consumer demands in new ways, which is critical to our modern economy - and which was observed during the first iteration of the inhospitality tradition. ${ }^{211}$ There is no evidence today to suggest that the benefits of any such regime would outweigh its costs.

To the contrary, there is good reason to be concerned that the costs would not (and even that they could not) be outweighed. There is particular reason to be concerned about the distributional effects of those costs. As outlined above, the benefits the firms offering lower cost products and increased convenience to consumers tends disproportionately to benefit lower-income consumers. ${ }^{212}$ And big tech firms often fit both these characteristics - they tend to offer low- (or even zero) priced products and services and, simultaneously, often to enhance non-price factors like services and ease of use. Lower-income consumers are more sensitive to these kinds of changes - while enhancements disproportionately benefit them, any impairments tend to disproportionately harm them. ${ }^{213}$

Experience from the first iteration of inhospitality demonstrated that such a regime's propensity to impose costs and to cripple competition is very real. Courts during this time routinely, and sometimes explicitly, ruled in favor of higher prices (which disparately harmed lower-income consumers). The Supreme Court in Brown Shoe Co. v. United States, for instance, noted "occasional higher costs and prices might result from the maintenance of the fragmented industries and markets." 214 Moreover, the decisions frequently undermined competition itself, while simultaneously failing to foster the other sociopolitical goals they espoused. ${ }^{215}$ As Herbert

211. See supra notes 133-35 and accompanying text; Wilson \& Klovers, supra note 207; supra Section I.A.

212. See supra Section III.A.

213. Note, moreover, that any regime that would trade off consumer welfare against other benefits would necessarily reduce consumer welfare. See Wright et al., supra note 18, at 363-66.

214. 370 U.S. 294, 344 (1962); see also Utah Pie Co. v. Cont'l Baking Co., 386 U.S. 685, 703 (1967) (reversing a ruling that would have allowed lower prices); United States v. Trans-Mo. Freight Ass'n, 166 U.S. 290, 323 (1897) (finding that conduct could be condemned when it would result in the "[m]ere reduction in the price of the commodity dealt in"); United States v. N.Y. Great A\&P Tea Co., 173 F.2d 79, 85-87 (7th Cir. 1949) (condemning a merger that would have allowed the parties to obtain products at cost because rival stores would continue to pay much higher prices to source those products).

215. See, e.g., United States v. Von's Grocery Co., 384 U.S. 270, 296-97 (1966) (Stewart, J., dissenting) ("The irony of this case is that the Court invokes its sweeping new construction of $\S 7$ to the detriment of a merger between two relatively successful, local, largely family-owned concerns, each of which had less than $5 \%$ of the local market and neither of which had any prior history of growth by acquisition."); United States v. Topco Assocs., Inc., 405 U.S. 596, 600 (1972) (condemning conduct that "improved the competitive potential of" the defendants); Hovenkamp, The Law of 
Hovenkamp explained, for instance, early efforts to promote small, locally owned enterprises by prohibiting exclusive dealing (a form of vertical arrangements) "completely destroyed" the very enterprises the decisions desired to protect - and "[r]esults of that sort were documented over and over." 216 It is critical to bear in mind, when crafting antitrust rules and reaching enforcement decisions, the incentives intervention and new legal standards would create. Indeed, as Hovenkamp notes, "[e]ven Justice Douglas, otherwise a progressive antitrust activist, foresaw the result" of requiring a manufacturer to allow its retailers to sell multiple brands would be to create manufacturer "empires" and to decimate small, independent businesses. ${ }^{217}$ Unfortunately, it would seem Justice Douglas had far greater foresight than many modern progressive antitrust proponents, who would embrace just such unsuccessful remedies today.

This analysis underscores that a new inhospitality approach would likely cost consumers tremendously, and would likely be most harmful to those consumers who can least afford it. History has much to teach us, if only we would listen.

\section{CONCLUSION}

Competition has long been the organizing principle of the American economy. Preserving healthy competition is, accordingly, paramount to supporting economic growth and consumer well-being. Firms in the big

Vertical Integration, supra note 26, at 884 ("[T] state it bluntly, legal policy often had the perverse effect of destroying the very small businesses it was intended to protect."); Elyse Dorsey et al., Hipster Antitrust Meets Public Choice Economics: The Consumer Welfare Standard, Rule of Law, and Rent Seeking, COMPETITION POL'y INT'L ANTITRUST Chron., Apr. 2018, at 1, 5-7 (examining the evidence of how antitrust decisions during the inhospitality era failed to foster the sociopolitical goals courts attempted to maximize); Noah Joshua Phillips, Commissioner, Fed. Trade Comm'n, Prepared Remarks at the Technology Policy Institute: "Looking Back to the Future: What the Past Can Tell Us About the Future of Antitrust" 11 (Nov. 15, 2018), https://www.ftc.gov/system/files/documents/public _statements/1456097/looking_back_to_the_future.pdf [https://perma.cc/739M-FLMZ] ("Court decisions before the economically-grounded consumer welfare standard did indeed protect smaller, inefficient competitors, at the expense of the average American who was less able to afford, for instance, groceries."); Makan Delrahim, Assistant Att'y Gen., Antitrust Div., U.S. Dep't of Justice, Stand By Me: The Consumer Welfare Standard and the First Amendment, Remarks at the Open Markets Institute Event: Antitrust and the News (June 12, 2018), https://www.justice.gov/opa/speech /assistant-attorney-general-makan-delrahim-delivers-remarks-open-markets-institute-event [https:// perma.cc/PE6Y-LEG5] ("[T]here could be real risks to core democratic values from abandoning the consumer welfare standard in pursuit of broader societal and democratic goals" under the antitrust laws).

216. Hovenkamp, Progressive Antitrust, supra note 18, at 84-85 (citing Standard Oil Co. of Cal. v. United States, 337 U.S. 293, 318-20 (1949) (Douglas, J., dissenting)); see also Hovenkamp, The Law of Vertical Integration, supra note 26, at 884-85 (further discussing Justice Douglas's dissent in Standard Oil).

217. Hovenkamp, Progressive Antitrust, supra note 18, at 84-85 (quoting Standard Oil, 337 U.S. at 318-20 (Douglas, J., dissenting)). 
tech space have continued to increase their prevalence within the modern economy over the last several decades. And so the current debate addressing how antitrust law can best promote competition in the big tech space is both timely and important. While critics warn that the harms they identify are unprecedented and require increasingly radical responses, the reality is that we have experience with just the type of inhospitality regime the more extreme critics argue is necessary. For decades, courts imposed the very kinds of broadscale skepticism and condemnation based solely upon the form of the conduct before them that proponents of a new inhospitality era support today.

But the result of the inhospitality regime's first iteration was not an enhancement in the consumer welfare or other sociopolitical goals the courts hoped such rules would facilitate. Instead, it was routinely observed that rules based upon the form of conduct, and divorced from the conduct's actual (or likely) effects, undermined the very goals those rules sought to achieve. Economists rigorously investigated these issues and discovered that much of the conduct being condemned had affirmatively procompetitive effects, which the courts' decisions were squelching; this discovery helped to explain the perverse outcomes they were repeatedly observing. As the new economic learning grew, so, too, did the courts' understanding of the issues before them. Rather than judging conduct on its form, the courts employed economic theory and evidence to make decisions based upon conduct's likely effects. Rather than judging the books by their covers, courts were now reading the books and judging them on their merits.

Enforcement efforts should follow not only theoretical models but also empirical evidence. Until the empirical case is built, calls to return to facial condemnation should be ardently resisted. We should not reject economic learning and evidence. Instead, we should continue to benefit from it, by basing our rules and standards upon the best available information. Today, the weight of the evidence demonstrates that consumers benefit tremendously from big tech, and that vertical arrangements, by and large, are procompetitive or competitively neutral. Combined, this evidence indicates that it is unlikely anything is fundamentally broken with competition in the big tech space, and that firms competing in adjacent and complementary markets is not inherently harmful. Antitrust policy and enforcement, in turn, should reflect that reality. While examples of harmful conduct might exist, they can be captured within the existing antitrust regime, and the wide-sweeping remedies many have proposed simply do not fit. The first inhospitality regime was incredibly costly to consumers. A second would likely be just as - if not more - harmful. 